\title{
Cell Adhesion, the Backbone of the Synapse: "Vertebrate" and "Invertebrate" Perspectives
}

\author{
Nikolaos Giagtzoglou', Cindy V. Ly', and Hugo J. Bellen ${ }^{1,2,3,4}$ \\ 'Howard Hughes Medical Institute, Baylor College of Medicine, Houston, Texas 77030 \\ ${ }^{2}$ Department of Neuroscience, Baylor College of Medicine, Houston, Texas 77030 \\ ${ }^{3}$ Department of Molecular and Human Genetics, Baylor College of Medicine, Houston, Texas 77030 \\ ${ }^{4}$ Program in Developmental Biology, Baylor College of Medicine, Houston, Texas 77030 \\ Correspondence: giagtzog@bcm.tmc.edu, hbellen@bcm.tmc.edu
}

Synapses are asymmetric intercellular junctions that mediate neuronal communication. The number, type, and connectivity patterns of synapses determine the formation, maintenance, and function of neural circuitries. The complexity and specificity of synaptogenesis relies upon modulation of adhesive properties, which regulate contact initiation, synapse formation, maturation, and functional plasticity. Disruption of adhesion may result in structural and functional imbalance that may lead to neurodevelopmental diseases, such as autism, or neurodegeneration, such as Alzheimer's disease. Therefore, understanding the roles of different adhesion protein families in synapse formation is crucial for unraveling the biology of neuronal circuit formation, as well as the pathogenesis of some brain disorders. The present review summarizes some of the knowledge that has been acquired in vertebrate and invertebrate genetic model organisms.

Cynapses are asymmetric, intercellular junctions that are the basic structural units of neuronal transmission. The correct development of synaptic specializations and the establishment of appropriate connectivity patterns are crucial for the assembly of functional neuronal circuits. Improper synapse formation and function may cause neurodevelopmental disorders, such as mental retardation (MsR) and autism spectrum disorders (ASD) (McAllister 2007; Sudhof 2008), and likely play a role in neurodegenerative disorders, such as Alzheimer's disease (AD) (Haass and Selkoe 2007).
At chemical synapses (reviewed in Sudhof 2004; Zhai and Bellen 2004; Waites et al. 2005; McAllister 2007; Jin and Garner 2008), the presynaptic compartment contains synaptic vesicles (SV), organized in functionally distinct subcellular pools. A subset of SVs docks to the presynaptic membrane around protein-dense release sites, named active zones (AZ). Upon the arrival of an action potential at the terminal, the docked and "primed" SVs fuse with the plasma membrane and release neurotransmitter molecules into the synaptic cleft. Depending on the type of synapse (i.e., excitatory vs. inhibitory synapses), neurotransmitters ultimately

Editors: W. James Nelson and Elaine Fuchs

Additional Perspectives on Cell Junctions available at www.cshperspectives.org

Copyright (C) 2009 Cold Spring Harbor Laboratory Press; all rights reserved; doi: 10.1101/cshperspect.a003079

Cite this article as Cold Spring Harb Perspect Biol 2009;1:a003079 
N. Giagtzoglou, C.V. Ly, and H.J. Bellen

A

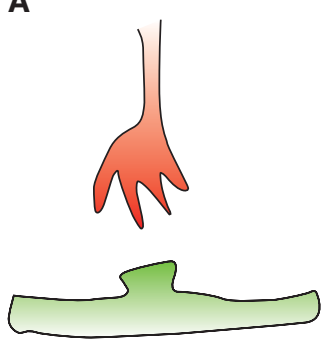

B

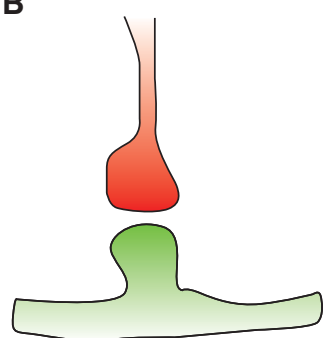

C

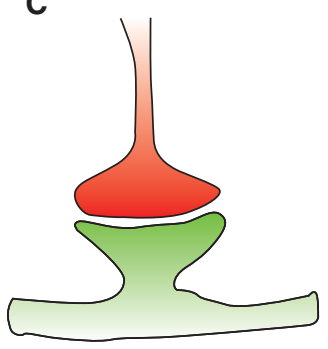

$\mathbf{F}$

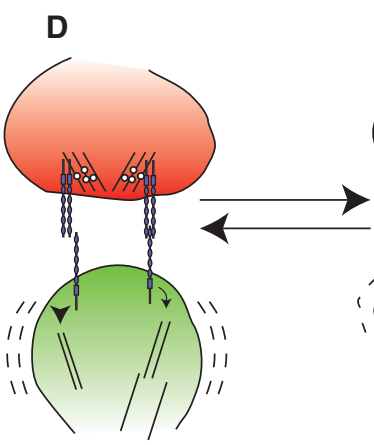

$\mathrm{E}$

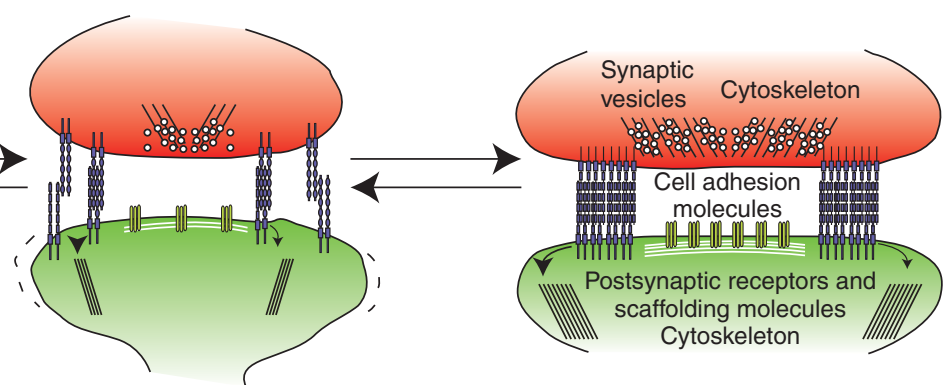

Figure 1. $(A-C)$ Different stages of synapse formation. (A) Target selection, $(B)$ Synapse assembly, $(C)$ Synapse maturation and stabilization. $(D-F)$ The role of cell adhesion molecules in synapse formation is exemplified by the paradigm of $\mathrm{N}$-cadherin and catenins in regulation of the morphology and strength of dendritic spine heads. (D) At an early stage the dendritic spines are elongated from motile structures "seeking" their synaptic partners. (E) The contacts between the presynaptic and postsynaptic compartments are stabilized by recruitment of additional cell adhesion molecules. Adhesional interactions activate downstream pathways that remodel the cytoskeleton and organize pre- and postsynaptic apparatuses. $(F)$ Cell adhesion complexes, stabilized by increased synaptic activity, promote the expansion of the dendritic spine head and the maturation/ stabilization of the synapse. Retraction and expansion is dependent on synaptic plasticity.

activate an appropriate set of postsynaptic receptors that are accurately apposed to the AZ.

Synapse formation occurs in several steps (Fig. 1) (reviewed in Eaton and Davis 2003; Goda and Davis 2003; Waites et al. 2005; Garner et al. 2006; Gerrow and El-Husseini 2006; McAllister 2007). Spatiotemporal signals guide axons through heterogeneous cellular environments to contact appropriate postsynaptic targets. At their destination, axonal growth cones initiate synaptogenesis through adhesive interactions with target cells. In the mammalian central nervous system (CNS), immature postsynaptic dendritic spines initially protrude as thin, actin-rich filopodia on the surface of dendrites. Similarly, at the Drosophila neuromuscular junction (NMJ), myopodia develop from the muscles (Ritzenthaler et al. 2000). The stabilization of intercellular contacts and their elaboration into mature, functional synapses involves cytoskeletal arrangements and recruitment of pre- and postsynaptic components to contact sites in spines and boutons. Conversely, retraction of contacts results in synaptic elimination. Both stabilization and retraction sculpt a functional neuronal circuitry.

In addition to the plastic nature of synapse formation, the vast heterogeneity of synapses (in terms of target selection, morphology, and type of neurotransmitter released) greatly enhances the complexity of synaptogenesis (reviewed in Craig and Boudin 2001; Craig et al. 2006; Gerrow and El-Husseini 2006). The complexity and specificity of synaptogenesis relies upon the modulation of adhesion between the pre- and postsynaptic components (reviewed in Craig et al. 2006; Gerrow and El-Husseini 2006; Piechotta et al. 2006; Dalva 
et al. 2007; Shapiro et al. 2007; Yamada and Nelson 2007; Gottmann 2008). Cell adhesive interactions enable cell-cell recognition via extracellular domains and also mediate intracellular signaling cascades that affect synapse morphology and organize scaffolding complexes. Thus, cell adhesion molecules (CAMs) coordinate multiple synaptogenic steps.

However, in vitro and in vivo studies of vertebrate CAMs are often at odds with each other. Indeed, there are no examples of mutants for synaptic CAMs that exhibit prominent defects in synapse formation. This apparent "resilience" of synapses is probably caused by functional redundancy or compensatory effects among different CAMs (Piechotta et al. 2006). Hence, studies using simpler organisms less riddled by redundancy, such as Caenorhabditis elegans and Drosophila, have aided in our understanding of the role that these molecules play in organizing synapses.

In this survey, we discuss the roles of the best characterized CAM families of proteins involved in synaptogenesis. Our focus is to highlight the complex principles that govern the molecular basis of synapse formation and function from a comparative perspective. We will present results from cell culture studies as well as in vivo analyses in vertebrate systems and refer to invertebrate studies, mainly performed in Drosophila and C. elegans, when they have provided important insights into the role of particular CAM protein families. However, we do not discuss secreted factors, for which we refer the reader to numerous excellent reviews (as for example Washbourne et al. 2004; Salinas 2005; Piechotta et al. 2006; Shapiro et al. 2006; Dalva 2007; Yamada and Nelson 2007; Biederer and Stagi 2008; Salinas and Zou 2008).

\section{THE NEUROLIGINS-NEUREXINS: SUFFICIENCY VERSUS NECESSITY}

The Neuroligin (Nlg)-Neurexin (Nrx) proteins play a major role in synapse formation and function (reviewed in Dean and Dresbach 2006; Dalva et al. 2007; Sudhof 2008). Neuroligins are type I membrane proteins consisting of an extracellular, catalytically inactive acetylcholinesterase domain that mediates binding to the following: neurexins, an O-glycosylation motif, a transmembrane (TM) domain, a cytoplasmic PDZ (post synaptic density protein [PSD95]), Drosophila disc large tumor suppressor (Dlg), and a zonula occludens-1 protein (zo-1) domain (Fig. 2) (Craig and Kang 2007; Sudhof 2008). There are four neuroligin genes in vertebrates, but alternative splicing increases the complexity of this protein family (Ichtchenko et al. 1996; Bolliger et al. 2001). Neuroligins, which are enriched postsynaptically, interact with presynaptic neurexins (Song et al. 1999). Three neurexin genes have been reported in mammals (Nrx 1-3), each with dual promoters that enable expression of two distinct protein isoforms, a long $\alpha$ - and a short $\beta$-isoform. The latter short isoforms bind to neuroligins (Tabuchi and Sudhof 2002; Sudhof 2008), neurexins contain adhesive, extracellular laminin, nectin, sexhormone binding globulin (LNS) domains prone to extensive alternative splicing (Fig. 2) (Rudenko et al. 1999, 2001). Though found presynaptically at both excitatory and inhibitory synapses (Ushkaryov et al. 1992; Ullrich et al. 1995; Dean et al. 2003; Graf et al. 2004), neurexins have also been reported to be present on postsynaptic cells (Kattenstroth et al. 2004; Taniguchi et al. 2007).

Neuroligins induce presynaptic differentiation of contacting neurites when expressed in heterologous nonneuronal cells (Scheiffele et al. 2000) and regulate synapse number and spine density in cell culture (Chih et al. 2005). In addition, recruitment of PSD-95 to the Neuroligin PDZ domain clusters NMDA receptors and other postsynaptic proteins (Fig. 2) (Chih et al. 2004). Neurexin overexpression in heterophilic cells induces postsynaptic differentiation of contacting neurites in vitro (Graf et al. 2004; Nam and Chen 2005; Chih et al. 2006). Neurexin signaling induces presynaptic specialization and is linked with the synaptic release machinery, voltage gated calcium channel (VGCC) clustering, and actin cytoskeletal changes (Hata et al. 1996; Butz et al. 1998; Biederer and Sudhof 2000; Atasoy et al. 2007). 
N. Giagtzoglou, C.V. Ly, and H.J. Bellen

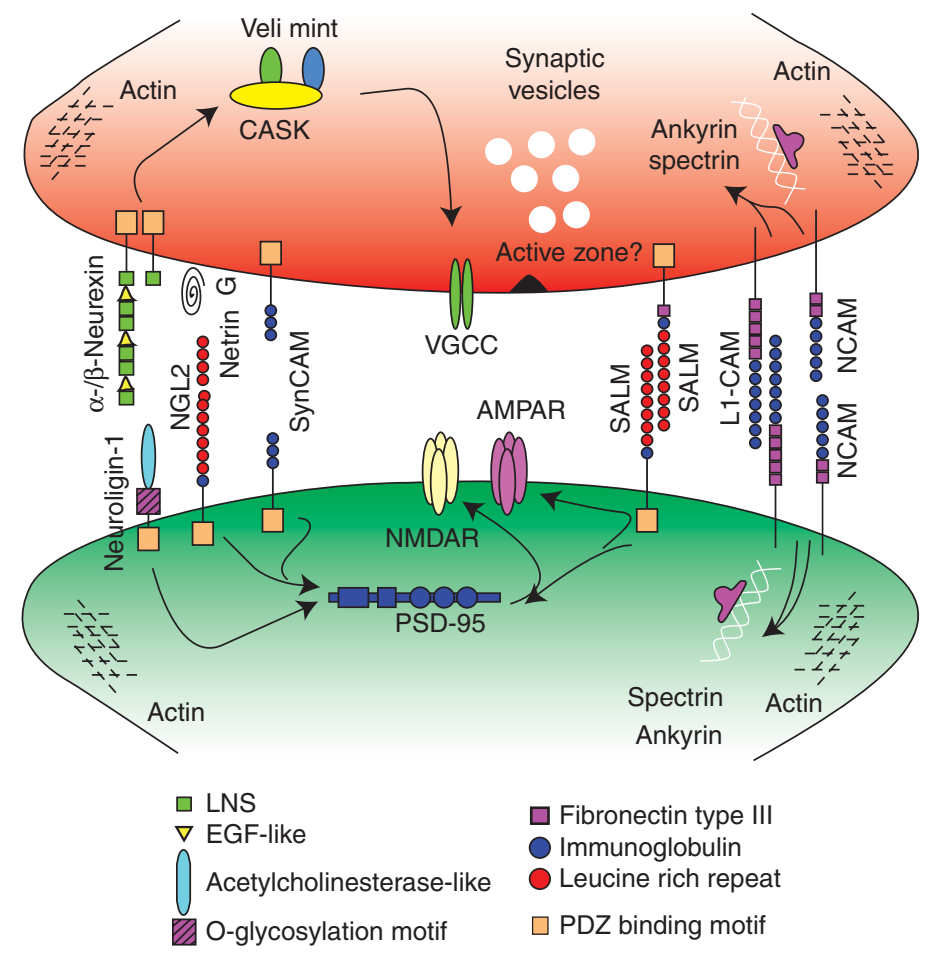

Figure 2. Diagram of Nrx - Nlg, LRR, and Ig mediated adhesion at excitatory synapses. Neurexins participate in the organization of presynaptic apparatuses and are linked to the synaptic vesicle cycle through interaction with CASK/Mint/Veli. Neuroligins interact with the postsynaptic PDZ scaffolding molecule PSD-95, which organizes the postsynaptic receptors (mainly NMDAR). Neurexins and neuroligins also participate at inhibitory synapses. Therefore, they are important for the balance of excitatory and inhibitory neurotransmission. Postsynaptic NGL2 binds to presynaptic GPI anchored Netrin G. NGL2 binds to the postsynaptic PDZ scaffolding molecule PSD95 and recruits NMDAR, but not AMPAR, in coculture experiments. SALM family members regulate the differentiation of neurites, organize postsynaptic sites by interacting with PSD-95, and recruit mainly NMDAR, and to a lesser extend AMPAR, in coculture experiments. Although no effects of SALMs on presynaptic organization are known, SALMs form distinct homophilic and heterophilic interactions suggesting adhesive roles on both sides of synapses. Ig molecules participate in both the structural and the functional organization of the synapse. SynCAM forms preferentially heterophilic interactions and induces synapse formation in coculture experiments. Presynaptically, it participates in the functional organization of the terminal through the interaction with CASK/Mint/Veli complexes. Postsynaptically, it interacts with the scaffolding molecule PSD-95. NCAM and L1-CAM form homophilic complexes and regulate cytoskeleton dynamics pre- and postsynaptically through interactions with spectrin and ankyrin.

In summary, the neurexin-neuroligin interactions are sufficient in cell culture assays to induce synapse formation, suggesting that they play a critical role in synapse formation.

The synaptogenic activities of $\mathrm{Nlg}$ and Nrx depend on their physical interaction (Scheiffele et al. 2000). These heterophilic associations regulate both excitatory and inhibitory synaptogenesis. Their ability to define different synapse types likely involves cell-type specific localization, as well as particular neuroliginneurexin combinations (Boucard et al. 2005; Chih et al. 2006). For example, Nlg-1 and -4 exclusively localize to excitatory synapses, whereas Nlg-2 is found only at inhibitory synapses, suggesting distinct roles at these terminals (Graf et al. 2004; Song et al. 1999; Varoqueaux et al. 2004). Nlg-3 can be found at both types of synapses (Budreck and Scheiffele 2007). Interestingly, an insert in splice site B of Nlg-1 
disrupts binding to $\operatorname{Nrx}-1 \beta$ and favors its localization to excitatory synapses. On the other end, Nlg-1 isoforms without the insert in splice site $\mathrm{B}$ bind to both $\alpha$ - and $\beta$-neurexins (Boucard et al. 2005; Chih et al. 2006). Hence, subtype and splice code variants of neurexin and neuroligin may dictate their binding specificity and roles in functional differentiation during synapse formation (Dalva et al. 2007).

The aforementioned data indicate that the Nrx-Nlg axis is sufficient to induce synapse formation in cell culture. However, in vivo studies paint a different picture. Removal of Nlg $1-3$ or $\alpha-N r x$ in mice does not support a singular inductive role for these proteins (Missler et al. 2003; Varoqueaux et al. 2006). Nlg triple knockout mice die soon after birth from respiratory failure, likely because of a subtle synaptic imbalance of excitatory and inhibitory synapses in the brainstem, although synapse numbers in most areas of the brain, including respiratory centers, are intact (Varoqueaux et al. 2006). Similarly, $\alpha$-Nrx triple knockout mice exhibit neonatal lethality and reduced synaptic transmission at both excitatory and inhibitory synapses (Missler et al. 2003), though synapse number and morphology are also unaffected (Dudanova et al. 2007). Electrophysiological studies, however, indicate a requirement for a presynaptic function of the neurexins and a role in regulating the activity of synaptic $\mathrm{Ca}^{2+}$ channels (Missler 2003). Hence, the in vivo analysis indicates that the $\mathrm{Nrx}-\mathrm{Nlg}$ proteins are sufficient in vitro but not necessary in vivo for synapse formation. Redundancy with other CAM proteins may underlie the apparent discrepancy between in vitro and in vivo studies. Alternatively, the $\mathrm{Nrx}-\mathrm{Nlg}$ may be required in synapse stabilization at a later stage.

Drosophila contains a single neurexin $(d n r x)$ and a single neuroligin gene homologous to the vertebrate counterparts (Tabuchi and Sudhof 2002; Li et al. 2007; Zeng et al. 2007). A neurexin IV has been reported in Drosophila, but this protein is clearly less homologous to Nrx I and was later shown to be more similar to the vertebrate Caspr protein (Bhat et al. 2001). Both NrxIV and Caspr were shown to play a role in septate junction formation and axon insulation in flies and mice (Baumgartner et al. 1996; Bhat et al. 2001). dNrx ( $\alpha$-neurexin) is expressed in neurons and localizes to active zones at the NMJ (Li et al. 2007). dnrxl controls synapse growth, differentiation, and function, in agreement with a synaptogenic role for neurexin proteins. Overexpression of $d n r x$ leads to synaptic overgrowth. Conversely, loss of $d n r x$ leads to a reduction of the number of synaptic boutons at the NMJ and misalignment of the pre- and postsynaptic compartments. The SV protein synaptotagmin and the $\mathrm{AZ}$ protein Bruchpilot are mislocalized in $d n r x$ mutant axons, indicating a role in the recruitment, localization, or transport of key synaptic components ( $\mathrm{Li}$ et al. 2007). Future studies in Drosophila should shed a better insight into how the neuroliginneurexin system regulates synapse development. An important step will be to determine whether the Drosophila Nlg gene, which reportedly exhibits the same spatiotemporal pattern of expression as dNrx, also affects synapse growth and function (Li et al. 2007).

In summary, neurexins and neuroligins are not absolutely required to form synapses, but they clearly play a role in the formation of the ultrastructural morphological features of synapses in flies and affect synapse function in vertebrates in vivo. These observations also emphasize the importance of carrying out in vivo experiments as they reveal a higher order of complexity than the in vitro cell culture data.

\section{LEUCINE RICH REPEAT (LRR) PROTEINS}

The leucine rich repeat (LRR) motifs are 20-29 amino acid (aa)-long protein interaction sequences, present in extracellular domains of a wide range of transmembrane as well as cytosolic proteins. Many LRR proteins regulate neurite outgrowth and migration (reviewed in Ko and Kim 2007), but two specific members of this family have been implicated in synaptogenesis: the netrin-G ligand (NGL) and the synaptic-like adhesion molecule (SALM) (Fig. 2).

The NGL family is composed of three type I transmembrane members, NGL 1-3. The NGL proteins contain nine LRR extracellular 
interaction domains, immunoglobulin (Ig) domains, a TM domain, and a PDZ motif, which interacts with PSD-95 (Fig. 2) (reviewed in Ko and Kim 2007). Extracellularly, the NGLs associate with netrin-G1 or netrin-G2, a family of netrin-like cell adhesion molecules, with a great number of spatiotemporally regulated splice variants, mainly expressed in the brain. NGL1 interacts with netrin-G1 (and possibly with other receptors as well) to regulate the growth of thalamocortical axons (Lin et al. 2003).

Interestingly, the NGL/netrin-G system shares key functional features with the $\mathrm{Nlg}$ Nrx axis. Overexpression of NGL in nonneuronal cells in vitro induces the differentiation of presynapses in contacting axons of cocultured neurons, although overexpression of netrin- $\mathrm{G}$ does not have the reciprocal capacity of inducing postsynaptic differentiation, as observed for Nrx (Kim et al. 2006). The possibility that netrin-G might not be the only ligand for NGLs may account for the unidirectional synaptogenic activity. For example, NGL3 does not interact with any of the netrin-G ligands (Kim et al. 2006). Furthermore, putative isoform specific interactions increase both the complexity and redundancy of adhesion. A role in synapse formation is further supported by the elevated expression levels of NGL in the brain postnatally and the ability of NGL-2 to induce clustering of NMDA receptors at excitatory synapses (Fig. 2) (Kim et al. 2006).

Interestingly, in C. elegans, a molecule distantly related to netrin-G, called netrin (a ligand for netrin receptors), is secreted by glial cells and plays a dual role in a pair of specific interneurons (Colon-Ramos et al. 2007). In this experimental system, netrin guides the axon of the postsynaptic neuron to the glial site of secretion, but unexpectedly, also orchestrates the differentiation of presynaptic boutons.

The SALM family of adhesion molecules contains five members in vertebrates. SALMs contain six LRR domains, an Ig domain, and a fibronectin III domain, followed by a transmembrane region and carboxy-terminal PDZ binding motif that interacts with PSD-95
(Fig. 2) (Ko et al. 2006; Ko and Kim 2007). The SALMs are mainly expressed in the brain. SALM-1 overexpression promotes excitatory synapse maturation and NMDA receptor clustering (Wang et al. 2006). SALM-2 regulates the number of excitatory synapses in cocultured neurons and associates with AMPA receptors more than with NMDA receptors (Ko et al. 2006; Wang et al. 2006). SALMs form distinct homo- and heterophilic interactions, suggesting adhesive roles pre- and postsynaptically (Seabold et al. 2008). However, the ligands and the nature of the molecular interactions of different SALMS need to be further elucidated.

Interestingly, in Drosophila, an overexpression genetic screen was recently conducted to identify novel cell membrane and secreted molecules with a role in target selection by the motor neuron axons (Kurusu et al. 2008). Out of 55 genes that were found to affect muscle targeting of motor axons and/or NMJ arborization patterns, 16 belong to the LRR family, including the tartan and capricious genes. Capricious is involved in target selectivity of both motor neuron and photoreceptor axons (Shishido et al. 1998; Shinza-Kameda et al. 2006). Tartan and Capricious cooperate in axonal pathfinding and have interchangeable extracellular domains (Kurusu et al. 2008).

In summary, LRR proteins play an important role in various aspects of neuronal development. However, additional studies are necessary to identify their mode of action in synaptogenesis.

\section{CONTROL OF SYNAPTOGENESIS BY MEMBERS OF THE IG SUPERFAMILY}

The Ig superfamily is the largest, most diverse, and most ancient superfamily represented in the genomes of both vertebrate and invertebrate organisms (Vogel et al. 2003). Members of the Ig protein family are single-pass type I transmembrane proteins that contain variable numbers of globular, extracellular, cysteine looped, Ig or Ig-like domains that mediate homophilic or heterophilic interactions. They are typically followed by fibronectin III type 
repeats (Fig. 2) (reviewed in Walsh and Doherty 1997; Piechotta et al. 2006).

\section{The Synaptic Cell Adhesion Molecule (SynCAM)}

The family of synaptic cell adhesion molecules (SynCAM) proteins, SynCAM1-4 (Biederer 2006), are expressed in the nervous system, where they constitute a trans-synaptic adhesion system (Fig. 2). SynCAMs can undergo further alternative splicing and are often posttranslationally modified through glycosylation (Fogel et al. 2007), thus increasing their complexity. The differential expression pattern and the heterophilic pattern of interactions among SynCAMs establish an adhesion code for neuronal circuitry formation (Biederer and Stagi 2008; Thomas et al. 2008).

SynCAM1 (also named nectin-like 2) localizes to both sides of the synaptic cleft. SynCAM1 can trigger the differentiation of functional presynaptic specializations in the axons of cocultured neurons (Fig. 2), similarly to Nlg (Biederer et al. 2002), although the induced synapses may be functionally distinct (Sara et al. 2005). Upon coexpression of SynCAM with glutamate receptors in HEK cells, glutamate-receptor-mediated currents can be detected (Biederer et al. 2002). The synaptogenic effect of SynCAM might be mediated through interaction of intracellular motifs (common among all members of SynCAM) with FERM (fourpoint-one, ezrin, radixin, and moesin) domains of cytoskeletal adaptors and PDZ domains of synaptic scaffolding proteins, such as CASK and syntenin (Fig. 2) (Biederer and Stagi 2008).

Despite the potent synaptogenic activity of SynCAM1 in vitro, SynCAM 1 knockout mutant mice are viable and fertile and synaptogenesis is not altered, possibly because of functional redundancy with other SynCAM proteins or compensation by other adhesion signaling complexes (Fujita et al. 2006; van der Weyden et al. 2006). Hence, redundancy is a recurrent theme to explain the lack of expected phenotypes when these proteins with potent in vitro functions are removed in vivo.
Neural Cell Adhesion Molecule (NCAM)

Neural cell adhesion molecule (NCAM) was one of the first membrane proteins implicated in cell adhesion between neurons. Three isoforms are produced from a single gene, one of which is glycosyl-phospahtidyl-inositol (GPI) linked to the membrane, whereas the other two are transmembrane molecules. NCAM regulates synapse formation, maturation, and function through homo- and heterophilic interactions (Fig. 2).

In vertebrates, NCAM localizes to developing synapses (Uryu et al. 1999) and its expression is activity-dependent (Schuster et al. 1998). Excitatory synapse density is reduced in NCAM-deficient cells when cocultured with wild-type neurons (Dityatev et al. 2000). Interestingly, synaptogenesis in this context depends on postsynaptic NCAM, its modification with polysialic acid (PSA) and activation of NMDA and fibroblast growth factor (FGF) receptors (Dityatev et al. 2004). However, synapse numbers from cultures of NCAM-deficient neurons alone are not different from wild-type cultures. Furthermore, mice lacking all three isoforms of NCAM are viable and fertile, although synaptic plasticity is impaired (Cremer et al. 1994; Muller et al. 1996; Cremer et al. 2000; Eckhardt et al. 2000; Bukalo et al. 2004). Synaptic transmission and vesicle dynamics at NCAM-deficient neuromuscular junctions are also altered (PoloParada et al. 2001). Hence, NCAM is essential for synapse function, but not synapse formation, possibly because of redundancy or compensation by other adhesion molecules. Alternatively, NCAM might only play a role in synaptic plasticity.

In Drosophila, fasciclin II (Fas II) is the only ortholog of vertebrate NCAM (reviewed in Packard et al. 2003; Kristiansen and Hortsch 2008). Similar to NCAM, there are three major protein isoforms of Fas II, two of which are transmembrane proteins and one that is GPI-anchored to the cell membrane. However, unlike the vertebrate homologs, none of the Fas II protein isoforms is modified by PSA. Fas II is expressed in numerous tissues, 
including the developing nervous system. Notably, the GPI-anchored isoform is expressed in nonneuronal cell types, especially glial cells where it provides an adhesive signal for guiding extending axons. The role of Fas II has been studied in the context of axonal pathfinding, synapse growth, and function at the NMJ and in the CNS.

Fas II is expressed in motor neuron axons and is especially enriched in their growth cones (Schuster et al. 1996a,b). Upon contact of the motor axon with the target muscle at the NMJ and initiation of synapse formation, Fas II becomes enriched pre- and postsynaptically. Overexpression of Fas II in the muscle affects target-selection and changes neuronal connectivity (Davis et al. 1997). However, in the absence of Fas II, synapses still form but eventually retract, suggesting that Fas II is not required for synapse induction, but rather stabilizes the nascent synapse (Schuster et al. 1996a,b). Lack of stability allows or induces dynamic structural changes during synapse growth. Indeed, reduced levels of Fas II allow synapse growth and sprouting in mutant flies (Schuster et al. 1996a,b). Interestingly, mutations that presynaptically increase synaptic activity by affecting cyclic AMP (cAMP) degradation result in reduction of FasII and expansion of the NMJ arborization pattern (Budnik et al. 1990; Zhong et al. 1992). Postsynaptically, Fas II localization at the NMJ is regulated through interaction with Dlg (the fly homolog of PSD-95) (Thomas et al. 1997). $\mathrm{Ca}^{2+}$-calmodulin protein kinase II (CaMKII) phosphorylates Dlg in an activity-dependent manner, causing the dissociation of Dlg from the postsynaptic density, reducing the binding of Dlg with FasII. This results in declustering and removal of Fas II from the synapse, thereby allowing an expansion of the synapse (Koh et al. 1999).

In the CNS, Fas II is not required for initial synapse formation, similarly to the principles of NMJ development, but a lack of balance between the pre- and postsynaptic levels of Fas II causes a decrease in synaptic input to the motor neurons and a reduction of the number of synapses (Baines et al. 2002). Fas II regulates synaptic function, and this has been documented in learning and memory related studies. Fas II is expressed in the axons of the mushroom bodies, the learning centers of the fly brain, where it is involved in memory storage, and maintenance and retrieval of memory (Cheng et al. 2001).

\section{L1-CAM}

In vertebrates, L1-CAM, neurofascin, Nr-CAM, and CHL1 comprise the L1-type CAM protein group. L1-CAM interacts both homophilicaly and heterophilicaly. L1 is present in the CNS at the onset of differentiation. The highly conserved intracellular domains of most L1-type proteins contain ankyrin and FERM binding motifs linking it to spectrin and the actin cytoskeleton (Fig. 2) (Davis and Bennett 1994; Dickson et al. 2002; Cheng et al. 2005). However, L1 can also interact with microtubule stabilizing proteins such as doublecortin (Kizhatil et al. 2002).

L1-type proteins play a role in cell migration, neurite extension, axon pathfinding, myelination, fasciculation, synapse targeting, and long term potentiation (LTP) (Crossin and Krushel 2000; Gerrow and El-Husseini 2006; Piechotta et al. 2006; Maness and Schachner 2007). The L1-CAM gene is causally related to a variety of neurological disorders that are associated with mental retardation, hydrocephalus, and spasticity of the lower limbs (CRASH syndrome) (Fransen et al. 1995, 1997; Bateman et al. 1996; Fransen et al. 1997; Kenwrick and Doherty 1998; Kenwrick et al. 2000; De Angelis et al. 2002). Two L1-CAM knockout mice strains were independently generated (Dahme et al. 1997; Cohen et al. 1998). Dahme et al. (1997) reported that deletion of L1-CAM causes a high rate of embryonic lethality and compromises the postnatal survival of knockout mice, which also display a deficiency of peripheral sensory and motor innervation, a reduction of the corticospinal tract, an enlargement of the cerebral ventricles, and an impaired axon-Schwann cell association (Dahme et al. 1997). In other studies, the L1 knockout mice were viable but exhibited an axon guidance 
defect in the corticospinal tract, disturbed axonal targeting, altered dendritic morphology and orientation, and abnormalities of spatial learning and exploratory behavior (Cohen et al. 1998; Fransen et al. 1998; Demyanenko et al. 1999, 2001). An electrophysiological study of L1 mice has revealed a reduction of $\gamma$-aminobutyric acid (GABA)-ergic transmission in the CA1 region of the hippocampus. Morphologically, a corresponding decrease in the density of perisomatic symmetrical synapses has been observed and synaptic vesicles show a more diffuse distribution (Saghatelyan et al. 2004). In a hippocampus-specific conditional L1-CAM knockout mouse model, basal excitatory transmission is enhanced in the mutant neurons and behavioral deficits are only partly similar to those observed in constitutive $\mathrm{L1}^{-/-}$mice (Law et al. 2003). The above findings suggest an involvement of L1 in the formation and/or maintenance of inhibitory synapses and imply that L1 might be functioning along with other cell adhesion systems.

The only homolog of L1-CAM in the fly is neuroglian (Nrg) (Bieber et al. 1989; Walsh and Doherty 1997; Kristiansen and Hortsch 2008). Two transcripts are generated encoding a short and a long isoform (Hortsch et al. 1990; Hall and Bieber 1997). The two isoforms differ in their cytoplasmic domains and the short isoform is expressed in epidermis, muscle, trachea, and glia, whereas the long isoform is restricted to the nervous system (Hortsch et al. 1990). Nrg plays a role in axon growth in the peripheral nervous system during embryonic and postembryonic development. Null $n r g$ mutations are lethal, and motor axons are stalled in embryos (Bieber et al. 1989; Hall and Bieber 1997; Martin et al. 2008). Neuronal expression of $\mathrm{Nrg}$ rescues the mutant phenotype suggesting that Nrg mediates heterophilic adhesion of the advancing axons with their substrate (Martin et al. 2008). In the adult ocellar sensory system, Nrg establishes two distinct axonal pathways, one originating from the bristle mechanoreceptors and the other originating from the ocellar pioneer neurons (Garcia-Alonso et al. 2000; Kristiansen et al. 2005). Especially in the ocellar pioneer neurons, Nrg functions redundantly with Fas II. Interestingly, it has been proposed that $\mathrm{Nrg}$ mediated activation of epidermal growth factor (EGF) and FGF receptors is needed for the pathfinding process (Garcia-Alonso et al. 2000).

It has been suggested that ankyrin-binding to L1-type CAMs provides a "master switch," so that L1-type adhesive proteins can function in different contexts: in an ankyrin-independent manner during neurite outgrowth and axonal pathfinding, or in ankyrin-dependent manner during synaptogenesis (Hortsch et al. 2009). Indeed, Nrg also functions along with the intracellular adaptor ankyrin to suppress axonal sprouting and dendritic branching in a subset of multidendritic neurons (Yamamoto et al. 2006) and control proper synapse formation and function in the giant fiber synapse by organizing the microtubules in the presynaptic terminals (Godenschwege et al. 2006). The significance of ankyrin in organizing the stability of presynaptic cytoskeleton is further supported by experiments at the fly NMJ, which show that in the absence of the neuronally expressed ankyrin 2, synapses retract, leaving behind "footprints" of postsynaptic specializations (Koch et al. 2008; Pielage et al. 2008). In addition, postsynaptic spectrin is necessary for the development and organization of both the presynaptic active zone and the opposing postsynaptic density (Pielage et al. 2006). It would be interesting to assess whether Nrg participates in these processes as well.

\section{Synaptogenesis Abnormal (SYG) -1 and -2}

In the C. elegans egg-laying circuitry, two transmembrane proteins, SYG-1 and SYG-2, control target recognition and synapse formation of the hermaphrodite specific motor neuron HSNL. SYG-2 is present on vulval epithelial cells and interacts with SYG-1, which is expressed on HSNL neuron (Shen and Bargmann 2003; Shen et al. 2004). Upon interaction with SYG-2, SYG-1 initiates the hierarchical assembly of presynaptic specializations in HSNL (Patel et al. 2006) by recruiting SYD-1 (a rhoGTPase activating protein factor) and 
SYD-2 (liprin- $\alpha$ ). Furthermore, the interaction of SYG-1 and SYG-2 enables SYG-1 to bind to SKR-1, an E3 ubiquitin ligase, and inhibit its activity, protecting the nascent synapses from proteasome mediated, aberrant elimination (Ding et al. 2007). syg-2 mutants lack synapses at the normal location and instead exhibit ectopic synapses and a reduced number of active zones (Shen et al. 2004). In syg-1 mutants, vesicles fail to accumulate at normal synaptic locations and form ectopic clusters instead (Shen and Bargmann 2003).

There are two SYG-1 homologs in Drosophila, irregular chiasm C-roughest (IrreC-Rst) and kin of IrreC also named dumbfounded (Kirre or Duf), and two SYG-2 homologs, sticks and stones (Sns) and Hibris (Chao and Shen 2008). SYG-1/IrreC/Kirre are homologous to Neph receptor and SYG-2/ Hibris/Sns are homologues of nephrin ligands (Chao and Shen 2008). IrreC-Rst, Kirre, and Hibris are involved in patterning of the Drosophila eye and in synaptic wiring of the visual system (Ramos et al. 1993; Bao and Cagan 2005; Carthew 2005, 2007; Bazigou et al. 2007). Heterophilic interactions between IrreC-Rst and Kirre, which are expressed in muscle founder cells with Hibris and Sns, respectively (which are expressed on fusion competent myoblasts), are important for Drosophila myoblast fusion (Bour et al. 2000; Ruiz-Gomez et al. 2000; Artero et al. 2001; Dworak et al. 2001; Strunkelnberg et al. 2001; Dworak and Sink 2002). Neph/nephrin are instrumental in kidney function (Patrakka and Tryggvason 2007). However, their expression pattern in the nervous system and their ability to interact with CASK implies that the vertebrate homologs may be involved in synapse formation as well (Gerke et al. 2006).

\section{THE INSTRUMENTAL ROLE OF LIPRIN- $\alpha$ AND LEUCOCYTE-COMMON ANTIGEN RELATED (LAR) PROTEINS IN SYNAPSE FORMATION AND ACTIVE ZONE MORPHOGENESIS}

Liprin- $\alpha$ family proteins contain an aminoterminal coiled coil domain and a carboxy- terminal liprin homology domain, comprised of three sterile $\alpha$ motifs (SAMs) (reviewed in Stryker and Johnson 2007). Through these motifs, liprin- $\alpha$ proteins interact with leucocyte-common antigen related (LAR) proteins. In vertebrates, there are four liprin- $\alpha$ (liprin $\alpha 1-4$ ) and three LAR (LAR, PTP- $\sigma$, and PTP- $\delta$ ) paralogues. Members of the LAR family are transmembrane tyrosine phosphatases with highly conserved extracellular and cytoplasmic domains. Their extracellular region is structurally similar to cell adhesion molecules of the Ig family. Intracellularly, the phosphatase domain proximal to the membrane possesses the majority of the catalytic activity, whereas the distal one seems to interact with numerous downstream effectors, including $\beta$-catenin and members of the liprin$\alpha$ protein family (reviewed in Stryker and Johnson 2007) (Fig. 3).

LAR and liprin- $\alpha$ regulate synapse formation and function (reviewed in Spangler and Hoogenraad 2007; Stryker and Johnson 2007). Presynaptically, mammalian liprin- $\alpha$ associates with two major synaptic complexes. One of the complexes is formed by liprin- $\alpha$ interacting through the coiled coil regions with the cytomatrix at the active zoneassociated structural protein (CAST) and Rab3-interacting molecule (RIM) (Fig. 3) (Ohtsuka et al. 2002; Schoch et al. 2002; Ko et al. 2003). The other complex liprin- $\alpha$ associates with is the mammalian-LIN-seven protein (MALS)-CASK-Mint complex (Olsen et al. 2005). Postsynaptically, liprin- $\alpha$ interacts with glutamate receptor interacting protein 1 (GRIP1), an AMPA receptor binding protein (Wyszynski et al. 2002)(Fig. 3). The interaction of LAR and liprin- $\alpha$ regulates AMPA receptor clustering and dendritic spine morphology. Intriguingly, the phosphatase activity of LAR and its interactions with liprin- $\alpha$ and GRIP1 regulate the delivery of cadherin $/ \beta$-catenin complexes during the development and maintenance of excitatory synapses (Dunah et al. 2005). Liprin- $\alpha$ is regulated by CAMKII. Overexpression of nondegradable mutant forms of liprin or dominant negative forms of LAR that cannot bind to liprin impair signaling 


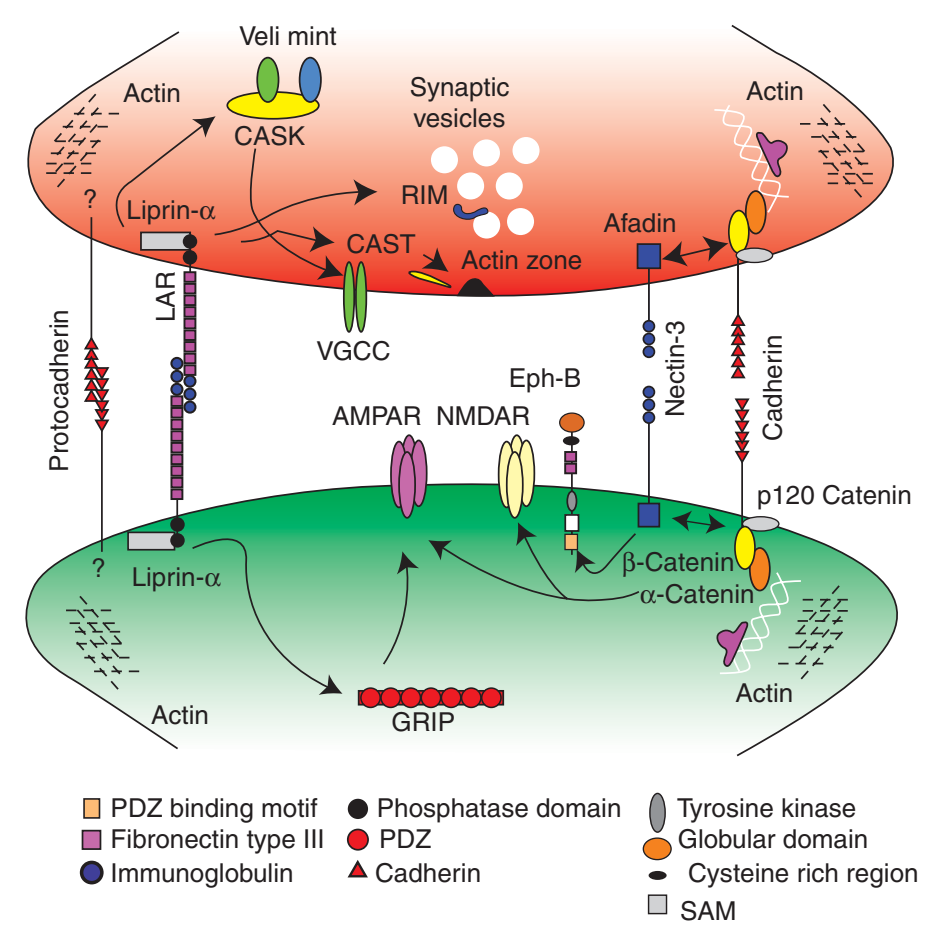

Figure 3. Diagram of LAR-liprin- $\alpha$ signaling and cadherin-nectin mediated adhesion at excitatory synapses. Liprin- $\alpha$ is the mediator of LAR signaling in both pre- and postsynaptic compartments. Thus, LAR/liprin- $\alpha$ complexes control neurotransmitter release and active zone formation through interactions with CAS/Mint/ Veli, RIM, and ERC. LAR/liprin- $\alpha$ complexes regulate the postsynaptic organization of neurotransmitter receptors through interaction with GRIP, an AMPAR interacting protein. Cadherins are localized at puncta adherentia, the region flanking the active zone, along with nectins. Cadherins form homophilic complexes. The intracellular domain of cadherins interacts with catenins that ultimately link cadherins to the cytoskeleton. Cadherins are the physical link between synaptic activity and dendritic spine morphology (see text and Fig. 1C-F). Cadherins also control the organization of postsynaptic receptors. Nectins form heterophilic complexes and are able to recruit cadherins, but they can also interact with other adhesions systems, such as ephrins. Nectins are indirectly linked to the cytoskeleton through Afadin.

and lead to a reduction of dendritic branching and spine density (Hoogenraad et al. 2007).

LAR-liprin- $\alpha$ signaling has been studied in C. elegans and Drosophila (reviewed in Stryker and Johnson 2007). In C. elegans, SYD-2 $($ liprin- $\alpha$ ) is required presynaptically for the formation of active zones and synaptic function (Zhen and Jin 1999). In addition, the localization of PTP-3A, one of the protein isoforms of LAR, is disrupted in syd-2 mutants. Mutants lacking PTP-3A phenocopy syd-2 mutants in terms of active zone organization (Zhen and Jin 1999). The precise localization at the synapse of PTP3A also depends on interactions of the extracellular Ig domains with nidogen, a sulfated glycoprotein, and animals lacking nidogen phenocopy $p t p-3 a$ and $s y d-2$ mutants (Ackley et al. 2005).

In Drosophila, fly LAR and liprin- $\alpha$ homologs are required in the visual system, along with $\mathrm{N}$-cadherin, at an early developmental stage for unbundling the R1-R6 afferent photoreceptor growth cones, so that they can project properly into assembling laminal cartridges (Clandinin et al. 2001; Choe et al. 2006) (also see Fig. 4). Unlike N-cadherin, which is required both pre- and postsynaptically (see the following discussion), liprin- $\alpha$ and LAR are required only in the presynaptic terminals, where they may regulate $\mathrm{N}$-cadherin 
N. Giagtzoglou, C.V. Ly, and H.J. Bellen

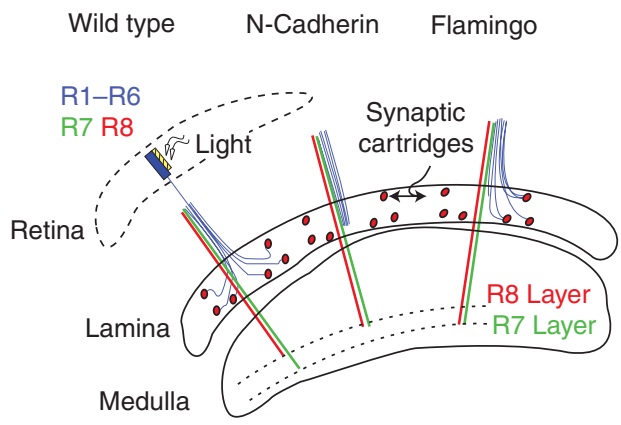

Figure 4. Synaptic wiring in the visual system of Drosophila. The compound eye of Drosophila is comprised of 750 ommatidia, each of which has eight photoreceptors, named R1-R8. Light stimulates the photoreceptors at the outer level of the retina, where the cell bodies lie. The signal is transmitted to the postsynaptic partners at the inner neuropils of the lamina and the medulla. R1R6 photoreceptor axons from each ommatidium stop at the lamina, where they defasciculate and innervate nearby synaptic cartridges according to the principle of neural superposition. R7 and R8 photoreceptor axons continue to the medulla, where they terminate at distinct layers. In loss of function of $\mathrm{N}$-cadherin, R1 and R6 fail to defasciculate, whereas $\mathrm{R} 7$ retracts to the wrong R8 specific layer. In loss of function of Flamingo cadherin, R1-R6 defasciculate but innervate abberrantly the synaptic cartridges, whereas the R8 photoreceptor axons terminate in the R7 layer (see text and also Mast et al. 2006; Ting and Lee 2007).

activity to establish a form of functional asymmetry (Clandinin et al. 2001; Choe et al. 2006). LAR and liprin- $\alpha$ are required for proper layer target selection of the R7 photoreceptor axons (Newsome et al. 2000; Maurel-Zaffran et al. 2001; Hofmeyer et al. 2006), where LAR and liprin- $\alpha$ form physical complexes. Although there is evidence of LAR independent liprin- $\alpha$ function in certain contexts (Hofmeyer et al. 2006), at the NMJ they control synapse growth and active zones formation together (Kaufmann et al. 2002). In the absence of LAR or liprin- $\alpha$, synapses are smaller and less elaborate than in wild-type animals, whereas presynaptic overexpression of LAR is adequate to increase synaptic size in a liprin- $\alpha$ dependent manner. Interestingly, liprin- $\alpha$ is normally down-regulated by the ubiquitinating activity of anaphase promoting complex (APC), which, when absent, results in stabilization of liprin- $\alpha$ and overgrown synapses (van Roessel et al. 2004). The interaction between liprin- $\alpha$ and APC is conserved in vertebrates (Hoogenraad et al. 2007).

Another parallel among Drosophila and C. elegans is the interaction with glycoproteins. Two heparin sulfate proteoglycans, syndecan $(\mathrm{sdc})$ and dallylike (dlp) regulate in opposite ways LAR activity. Sdc promotes LAR activity and synapse growth presynaptically, whereas Dlp inhibits it (Johnson et al. 2006). In the absence of $s d c$, synapse growth is impaired, similar to LAR and liprin- $\alpha$ mutants (Johnson et al. 2006). However, overexpression of Dlp postsynaptically inhibits LAR and results in decreased synaptic growth, whereas in parallel it increases the area of the active zones (Johnson et al. 2006), phenocopying in this manner LAR and liprin- $\alpha$ mutations (Kaufmann et al. 2002). Interestingly, in both mammalian cells and Drosophila, liprin- $\alpha$ interacts with KIF1A, a neuron specific motor transport protein, capable of interacting with synaptic proteins (Shin et al. 2003; Miller et al. 2005), indicating that LAR-liprin interactions regulate the recruitment of molecular complexes that mediate active zone and synapse formation.

\section{CADHERIN SUPERFAMILY}

Cadherins are involved in cell adhesion in numerous cell types in invertebrate and vertebrate organisms (reviewed in Shapiro et al. 2007; Takeichi 2007; Tai et al. 2008). Structurally, cadherins are single pass transmembrane molecules whose ectodomain contains a variable number of calcium binding cadherin repeats (Fig. 3). On the basis of their protein sequence, the domain structure, and the genomic organization, cadherins belong to two major branches, the cadherins and the cadherin related proteins, further subdivided into a total of six subfamilies (Nollet et al. 2000; Hulpiau and van Roy 2009). We mainly refer to the classical cadherins and protocadherins with respect to their role in the nervous system. 
Nonclassical Cadherins: Protocadherins and Flamingo (Fmi)

Protocadherins (Pcdh) are considered the primordial type of classical cadherins (reviewed in Frank and Kemler 2002). Protocadherins bear a variable number of cadherin repeats (Fig. 3). Based on their genomic organization and protein sequence, protocadherins are divided into the clustered and the nonclustered protocadherins (Redies et al. 2005; Morishita and Yagi 2007). All protocadherins undergo alternative splicing, and some members of the protocadherin family have region-specific expression patterns in the developing brain (Kohmura et al. 1998; Carroll et al. 2001; Hirano et al. 2002; Wang et al. 2002b; Phillips et al. 2003), providing an adhesive code for the establishment of specific brain structures (Serafini 1999; Shapiro and Colman 1999; Redies 2000; Shapiro et al. 2007). Moreover, protocadherins are localized to synaptic junctions and may modulate synaptic structure and transmission properties (Fig. 3) (Phillips et al. 2003).

The role of protocadherins in synapse formation and maturation has been documented genetically in null mutants for the Pcdh- $\gamma$ gene cluster. In $P c d h-\gamma^{-/-}$animals, there is an apoptotic degeneration of spinal interneurons, which leads to neonatal death (Wang et al. 2002a). Although prevention of cell death in mutants by removal of the proapoptotic Bax protein rescues the survival of the neurons, the density of synaptic puncta and of currents recorded from in vitro cultured neurons are still reduced, indicating a role of Pcdh- $\gamma$ in synaptogenesis (Weiner et al. 2005). The lack of general effects of Pcdh- $\gamma$ on the nervous system could be caused by compensation by $\operatorname{Pcdh}-\alpha$ and Pcdh- $\beta$. Further genetic analysis of Pcdh- $\alpha$ and Pcdh- $\beta$ mutants is needed.

CELSR 1 -3 belong to the Flamingo/CELSR group of cadherins and are characterized by seven transmembrane domains (Takeichi 2007). CELSR 2 and 3 have been implicated in nervous system development. Knockdown of CELSR2 results in retraction of dendrites,
Cell Adhesion, the Backbone of the Synapse

suggesting that the CELSR2 mediated homophilic interactions are important for maintenance of dendritic branching (Shima et al. 2004). Ablation of CELSR3 results in axonal tract defects (Tissir et al. 2005). The fly protein Flamingo (Fmi) is a unique nonclassical cadherin with seven transmembrane domains, that regulates planar cell polarity in epithelial cells ( $\mathrm{Lu}$ et al. 1999), dendritic tiling of peripheral neurons (Gao et al. 1999, 2000; Grueber 2002), and axon target selection in the visual system of Drosophila (Lee et al. 2003; Senti et al. 2003; Chen and Clandinin 2008). In the visual system, Fmi plays a role in both the lamina and the medulla neuropils (Fig. 4). In the medulla, Fmi is expressed in the afferent R7 and R8 photoreceptor axons, as well as in their target neurons. Fmi controls the layer target selection of R8 photoreceptor axons, which in the absence of Fmi retract to superficial layers (Lee et al. 2003; Senti et al. 2003). In addition, Fmi controls the tiling pattern of R8 axons, because mutations in Fmi cause a significant degree of overlap among the growth cones, as if the repulsion is impaired (Lee et al. 2003; Senti et al. 2003). In the lamina, Fmi functions strictly nonautonomously as a short-range, homophilic adhesive signal between specific R1-R6 photoreceptor cell growth cones, ensuring that the proper trajectory toward the assembling cartridges is followed (Chen and Clandinin 2008).

\section{Classical Cadherins}

Multiple classic cadherins exhibit distinct spatiotemporal patterns of expression (Suzuki et al. 1997; Inoue et al. 1998; Bekirov et al. 2002), suggesting that homophilic interactions among the extracellular cadherin repeats of different types of cadherins play a role in target recognition and synapse formation (Inoue et al. 1998; Miskevich et al. 1998; Wohrn et al. 1998; Ranscht 2000).

Classic cadherins and their associated partners, the catenins, localize at synapses preand postsynaptically (Fig. 3) (Yamagata et al. 1995, 2003; Fannon and Colman 1996; Uchida et al. 1996). In the mature synapse, the 
cadherin-catenin complexes are present in puncta adherentia, which are the regions flanking the active zone and are considered sites of mechanical adhesion (Uchida et al. 1996). $\mathrm{N}$-cadherin is cotransported with active zone components to sites of synapse formation (Jontes et al. 2004) and colocalizes with other synaptic markers (Benson and Tanaka 1998). Interestingly, $\mathrm{N}$-cadherin is retained mostly in excitatory and lost from inhibitory synapses (Benson and Tanaka 1998). The proximal region of the cytoplasmic domain of cadherins binds to p120-catenin family members, whereas the distal region binds to $\beta$-catenin (Fig. 3). $\beta$-catenins contain a PDZ domain that enables interactions with synaptic proteins (Arikkath and Reichardt 2008). The PDZ domain interacts with $\alpha$-catenin, which interacts with cytoskeletal actin binding proteins, such as $\alpha$-actinin or profilin (Fig. 3) (Pokutta and Weis 2007; Arikkath and Reichardt 2008). Clustering of cadherins may increase the critical concentration of $\alpha$-catenin locally, which may favor the formation of stable cell contacts by suppressing the Arp $2 / 3$ mediated actin polymerization (Pokutta and Weis 2007). Notably, the extracellular cadherin repeats are also able to bind to calcium $\left(\mathrm{Ca}^{2+}\right)$, which rigidifies the molecular structure of cadherins, enhances their dimerization, and stabilizes them by rendering them resistant to proteolytic degradation for extended periods of time (Fig. 1) (Shapiro et al. 2007). $\mathrm{Ca}^{2+}$ also reverses the inhibitory effect of peptides or antibodies directed against the extracellular domain of $\mathrm{N}$-cadherin (Tang et al. 1998). Thus, cadherins become trans-synaptic sensors of synaptic activity and regulators of both presynaptic and postsynaptic components. Indeed, synaptic activity stabilizes dimers of $\mathrm{N}$-cadherin and renders them more resistant to proteolytic degradation (Tanaka et al. 2000). NMDA activation retains $\mathrm{N}$-cadherin at the membrane by inhibiting its endocytosis (Tai et al. 2007). Activation of AMPA receptors on the other hand, leads to lateral expansion of the dendritic spine heads, during which $\mathrm{N}$-cadherin is redistributed to facilitate enhanced adhesion (Fig. 1) (Okamura et al. 2004).
Morphological changes in dendritic spines reflect alterations in synaptic strength (synaptic plasticity). Loss of function of $\mathrm{N}$-cadherin, $\beta$-catenin, or $\alpha$-catenin results in a less stable spine structure, reduction in the accumulation of pre- and postsynaptic markers, and impaired synaptic function (Elia et al. 2006; Jungling et al. 2006; Tanabe et al. 2006; Togashi et al. 2006; Okuda et al. 2007; Saglietti et al. 2007). $\mathrm{N}$-cadherin also regulates the trafficking of AMPA receptors (Nuriya and Huganir 2006; Saglietti et al. 2007) and postsynaptic loss of $\mathrm{N}$-cadherin causes defects in neurotransmitter exocytosis by presynaptic wild-type neurons (Jungling et al. 2006), suggesting a role in retrograde signaling. Loss of function of p120 (pre or post) catenin leads to decreased spine density, fewer mature spines, and mislocalization of pre- and postsynaptic components (Elia et al. 2006). Conversely, overexpression of $\alpha$-catenin increases dendritic spine density and stability (Abe et al. 2004).

Genetic analysis in Drosophila has greatly contributed to determining the function of $\mathrm{N}$-cadherins in vivo. Loss of $\mathrm{N}$-cadherin in Drosophila embryos causes the trajectories of longitudinal CNS axons and the guidance of growth cones to be affected (Iwai et al. 1997). The role of N-cadherins in synaptic "wiring" was more clearly shown by elegant studies in the visual (Fig. 4) and olfactory systems in Drosophila. N-cadherin is instrumental in the assembly of the visual neuronal circuitry, where it functions in the afferent axons of the R1-R6 photoreceptor sensory neurons as well as their target neurons in the lamina neuropil of the fly visual system (Prakash et al. 2005). Similarly, N-cadherin is crucial for the coordinated targeting of multiple neuronal types, such as R7 photoreceptor axons and L1-L5 lamina neurons, to the correct target layer in the medulla neuropil of the visual system (Lee et al. 2001; Nern et al. 2005, 2008; Ting et al. 2005). There are 12 isoforms of N-cadherin in the fly visual system, but the expression of a single isoform is able to rescue null mutations, suggesting functional redundancy (Ting et al. 2005). In the olfactory system, loss of $\mathrm{N}$-cadherin does not affect the pathfinding of 
olfactory receptor neuronal axons, but it influences their ability to converge onto a single glomerulus and form synapses (Hummel and Zipursky 2004). Similarly, the dendritic projections of the $\mathrm{N}$-cadherin mutant second-order neurons, which also innervate the olfactory lobes, expand on nonappropriate glomeruli (Zhu and Luo 2004). In both systems, $\mathrm{N}$-cadherin probably provides the adhesive force that mediates and stabilizes the attraction between neurites. The functions of $\mathrm{N}$-cadherins appear to be evolutionarily maintained. For example, misrouting of axon fibers has also been observed in the developing optic tract of $\mathrm{N}$-cadherin mutated zebrafish (Masai et al. 2003). Neurite nonextension/retraction has also been observed in cadherin blocked horizontal cell dendrites in the chicken retina (Tanabe et al. 2006).

\section{NECTINS-AFADIN}

Nectins (nectins 1-4) (reviewed in Takai et al. 2008a,b) are Ig-like transmembrane molecules with a pleiotropic role in cell-cell adhesion, cell movement, proliferation, survival, differentiation, polarization, and the entry of viruses (Fig. 3). All nectin genes have two or three splicing variants and are ubiquitously expressed (Takai et al. 2008a,b). Nectins interact in trans, in a $\mathrm{Ca}^{2+}$-independent manner through their extracellular regions with each other or with other Ig-like molecules (Takai et al. 2008a,b). They are anchored to the actin cytoskeleton, through the interaction of the carboxy-terminal of nectins with the PDZ domain of the actinbinding protein afadin, which, like nectins, are expressed ubiquitously (Takai et al. 2008a,b).

The nectin-afadin system resembles the cadherin-catenin system. Both systems colocalize at puncta adherentia junctions (Fig. 3) (Fannon and Colman 1996). Nectins recruit cadherins through the interaction with afadin, $\alpha$-catenin, and their binding proteins (Fig. 3) (Tachibana et al. 2000; Pokutta et al. 2002; Asada et al. 2003; Honda et al. 2003, 2006; Ooshio et al. 2004), with which they cooperate in vitro to regulate neurite overextension (Togashi et al. 2006). Afadin also binds to other cell adhesion systems, such as Eph receptors (Hock et al. 1998; Buchert et al. 1999), indicating how multiple cell adhesion complexes may operate cooperatively in the formation of junctional complexes (Fig. 3).

At synapses between mossy fiber terminals and the dendrites of CA3 pyramidal cells in the hippocampus of the adult brain, nectin-1 and -3 localize at presynaptic and postsynaptic sides, respectively, whereas afadin is symmetrically present at both sides (Fig. 3) (Mizoguchi et al. 2002). When presynaptic nectin-1 is blocked and interaction with postsynaptic nectin-3 is lost, the formation of synapses in hippocampal cell culture is impaired (Mizoguchi et al. 2002). However, nectin-1 and nectin-3 mutant mice are viable and fertile (except for male nectin-3 knockout mice). The mutant mice display micropthalmia, impairments of the mossy fiber tract, aberrantly localized afadin and $\mathrm{N}$-cadherin, and reduced number of puncta adherentia junctions at hippocampal synapses (Honda et al. 2006). In spite of these deficits, basic synaptic transmission and LTP at the mossy fiber synapse of nectin-1 knockout mice are identical to wild-type mice (Honda et al. 2006). These results suggest that there might be functional redundancy among different members of the family. However, disruption of the single afadin locus in mice, which consequently disrupts the function of all nectins (but also of other binding proteins) leads to embryonic lethality with pleiotropic defects, suggesting a widespread role of nectin-afadin in cell adhesion, migration, and differentiation (Ikeda et al. 1999).

In Drosophila, the nectin-afadin system could be paralleled by the echinoid-canoe complexes (Tepass and Harris 2007). Canoe is the fly homolog of afadin, which plays a pleiotropic role in morphogenesis. However, it is unknown if it serves a role in synapse formation and function. There is no clear homolog of nectins in Drosophila. The homophilic Ig-type adhesion protein Echinoid binds to canoe, as nectins bind to afadin, but there are many functional differences between echinoid and nectins (Tepass and Harris 2007). 
N. Giagtzoglou, C.V. Ly, and H.J. Bellen

\section{CONCLUDING REMARKS: GENETICS OF CELL ADHESION AND NEUROPSYCHIATRIC DISEASES}

Cell adhesion plays an important role in the maintenance and modulation of synaptogenic activity within neuronal circuitries. Synaptogenic cell adhesion molecules have been identified by a wide variety of methods, and their activity has been clearly assesed in in vitro synaptogenesis assays, where the complexity of trans-synaptic signaling is greatly simplified (Biederer and Scheiffele 2007; Sudhof 2008). However, "loss of function" in vivo studies often do not corroborate the in vitro results because of redundancy within a protein family and among different adhesive systems or because of subtle or different function. The intrinsic complexity and redundancy may also account for why so few components have been identified in forward genetic screens in flies and worms. Perhaps the lack of sensitivity of the screening assays in the past will be compensated for by current, more sophisticated tools. For example, screens for neuronal connectivity in the visual system of Drosophila (reviewed in Mast et al. 2006; Ting and Lee 2007) and synaptogenesis in C. elegans (Zhen and Jin 1999; Shen and Bargmann 2003) have illustrated the power of these approaches. Genetic screens can now be carried out in sensitized genetic backgrounds using GFP basedmarkers, such as GRASP (a split GFP method that relies upon reconstitution of GFP along synaptic partners) (Feinberg et al. 2008), and a combination of genetic methodologies and transcriptional profiling or computational methods (Jin and Garner 2008).

Synaptic function and structure may be the converging point of malfunction in neuropsychiatric disorders, such as mental retardation and autism (Geschwind and Levitt 2007; Geschwind 2008; Walsh et al. 2008; Kramer and van Bokhoven 2009). Subtle changes in the connectivity patterns of a subset of synapses or in their basal function (Geschwind and Levitt 2007; Krey and Dolmetsch 2007; Abrahams and Geschwind 2008; Geschwind 2008; Sudhof 2008) and plasticity (Ramocki and Zoghbi
2008) might alter dramatically the output of the neuronal circuitry. Interestingly, mutations in neurexin 1 and neuroligins 3 and 4 are associated with autism spectrum disorders and mental retardation (Sudhof 2008). The scaffolding molecule and interacting protein of neuroligin SHANK3 (ProSAP2) is also associated with autism (Durand et al. 2007). More than 140 different mutations in L1-CAM have been associated with neurological disorders, including mental retardation (Bateman et al. 1996; Kenwrick and Doherty 1998; Kenwrick et al. 2000; De Angelis et al. 2002).

The heritability of psychiatric disorders, such as bipolar disorder, schizophrenia, and autism, has been estimated to be significantly higher than that of cancer (Burmeister et al. 2008). However, the genetics of neuropsychiatric disorders are obscured by incomplete penetrance, variable expressivity, complex interactions among genetic and environmental factors, and imprecisely defined traits (Burmeister et al. 2008). Intriguingly, most of the genes associated with mental retardation are evolutionarily conserved in Drosophila (Inlow and Restifo 2004), which is regarded as a succesful model for human diseases (Bier 2005).

In conclusion, it is important to provide more candidate genes and a better, more detailed understanding of their in vivo role in model organisms in order to further unravel the complexity of synaptogenesis and its role in neuronal development, function, and disease.

\section{ABBREVIATIONS}

$\begin{array}{ll}\text { CASK } & \begin{array}{l}\mathrm{Ca}^{2+} / \text { calmodulin-dependent } \\ \text { serine protein kinase } \\ \text { amino acid }\end{array} \\ \text { aa } & \begin{array}{l}\text { Anaplastic lymphoma kinase } \\ \alpha \text {-amino-3-hydroxy-5-methyl-4- } \\ \text { ilk }\end{array} \\ \text { AMPA } & \text { AMPA receptors } \\ \text { AMPAR } & \text { Anaphase Promoting Complex } \\ \text { APC } & \text { Autism Spectrum Disorders } \\ \text { ASD } & \text { Brain Derived Neurotrophic } \\ \text { BDNF } & \text { Factor } \\ \text { BMP } & \text { Bone Morphogenetic Protein }\end{array}$


Cell Adhesion, the Backbone of the Synapse

\begin{tabular}{|c|c|}
\hline $\mathrm{Ca}^{2+}$ & Calcium \\
\hline CABAR & GABA receptors \\
\hline CAM & Cell Adhesion Molecule \\
\hline CAMKII & $\begin{array}{l}\mathrm{Ca} 2+/ \text { calmodulin dependent } \\
\text { protein kinase II }\end{array}$ \\
\hline CASK & $\begin{array}{l}\text { Calcium/calmodulin-dependent } \\
\text { serine protein kinase }\end{array}$ \\
\hline CAST & $\begin{array}{l}\text { cytomatrix at the active zone- } \\
\text { associated structural protein }\end{array}$ \\
\hline CNS & Central Nervous System \\
\hline DGC & dystrophin glycoprotein complex \\
\hline $\mathrm{dNrx}$ & Drosophila Neurexin \\
\hline Eph & $\begin{array}{l}\text { Erythropoietin-producing } \\
\text { hepatocellular carcinoma }\end{array}$ \\
\hline FAK & focal adhesion kinase \\
\hline FERM & $\begin{array}{l}\text { Four-point-one, Ezrin, Radixin } \\
\text { Moesin }\end{array}$ \\
\hline FGF & fibroblast growth factor \\
\hline Fmi & Flamingo \\
\hline GABA & $\gamma$-aminobutyric acid \\
\hline GAD & glutamate decarboxylase \\
\hline GEF & guanine exchange factor \\
\hline GPI & glycosyl-phospahtidyl-inositol \\
\hline GRB2 & $\begin{array}{l}\text { growth factor receptor-bound } \\
\text { protein } 2\end{array}$ \\
\hline GRIP & $\begin{array}{l}\text { glutamate receptor interacting } \\
\text { protein }\end{array}$ \\
\hline HEK & Human Embryonic Kindey \\
\hline $\operatorname{Ig}$ & Immunoglobulin \\
\hline LAR & $\begin{array}{l}\text { leucocyte-common antigen } \\
\text { related }\end{array}$ \\
\hline LNS & $\begin{array}{l}\text { Laminin, Nectin, Sex-hormone } \\
\text { binding globulin }\end{array}$ \\
\hline LRR & Leucine Rich Repeat \\
\hline MALS & Mammalian-LIN-seven protein \\
\hline Mint & Munc-18 interacting protein \\
\hline MR & Mental Retardation \\
\hline Narp & $\begin{array}{l}\text { Neuronal activity-regulated } \\
\text { pentraxin }\end{array}$ \\
\hline NCAM & Neural Cell Adhesion Molecule \\
\hline NGL & Netrin-G Ligand \\
\hline $\mathrm{Nlg}$ & Neuroligin \\
\hline NMDA & N-methyl-D-aspartate \\
\hline NMDAR & NMDA receptors \\
\hline NMJ & Neuromuscular Junction \\
\hline Nrx & Neurexin \\
\hline N-terminal & aminoterminal \\
\hline PAK & p21-activated kinase \\
\hline PAK & P21-activated kinase \\
\hline
\end{tabular}

Pcdh protocadherins

PDZ post synaptic density protein (PSD95), Drosophila disc large tumor suppressor(Dlg), zonula occludens-1 protein (zo-1)

PSA polysialic acid

PSD PSD

PTP Protein tyrosine phosphatase

RIM Rab3-Interacting Molecule

SALM Synaptic Adhesion Like Molecule

SAM sterile $\alpha$ motifs

S-SCAM synaptic scaffolding molecule

SV Synaptic Vesicles

SYD-2 synaptogenesis defective

SynCAM Synaptic Cell Adhesion Molecule

TEM Transmission Electron

TM Transmembrane

Veli vertebrate LIN-7

\section{ACKNOWLEDGMENTS}

We are grateful to Manish Jaiswal and Tomoko Ohyama for their insightful comments during the preparation of the manuscript. Nikolaos Giagtzoglou is supported by a long-term European Molecular Biology Organization postdoctoral fellowship and the Howard Hughes Medical Institute. Cindy V. Ly is supported by a Ruth L. Kirschstein National Research Service Award from the National Institute of Neurological Disorders and Stroke. Hugo J. Bellen is a Howard Hughes Medical Institute Investigator. N.G. and C.V.L. contributed equally to this work.

\section{REFERENCES}

\footnotetext{
Abe K, Chisaka O, Van Roy F, Takeichi M. 2004. Stability of dendritic spines and synaptic contacts is controlled by $\alpha$ N-catenin. Nat Neurosci 7: 357-363.

Abrahams BS, Geschwind DH. 2008. Advances in autism genetics: On the threshold of a new neurobiology. Nat Rev Genet 9: 341-355.

Ackley BD, Harrington RJ, Hudson ML, Williams L, Kenyon CJ, Chisholm AD, Jin Y. 2005. The two isoforms of the Caenorhabditis elegans leukocyte-common antigen related receptor tyrosine phosphatase PTP-3 function independently in axon guidance and synapse formation. J Neurosci 25: 7517-7528.

Arikkath J, Reichardt LF. 2008. Cadherins and catenins at synapses: Roles in synaptogenesis and synaptic plasticity. Trends Neurosci 31: 487-494.
} 
Artero RD, Castanon I, Baylies MK. 2001. The immunoglobulin-like protein Hibris functions as a dose-dependent regulator of myoblast fusion and is differentially controlled by Ras and Notch signaling. Development 128: 4251-4264.

Asada M, Irie K, Morimoto K, Yamada A, Ikeda W, Takeuchi M, Takai Y. 2003. ADIP, a novel Afadin- and $\alpha$-actinin-binding protein localized at cell-cell adherens junctions. J Biol Chem 278: 4103-4111.

Atasoy D, Schoch S, Ho A, Nadasy KA, Liu X, Zhang W, Mukherjee K, Nosyreva ED, Fernandez-Chacon R, Missler M, et al. 2007. Deletion of CASK in mice is lethal and impairs synaptic function. Proc Natl Acad Sci 104: 2525-2530.

Baines RA, Seugnet L, Thompson A, Salvaterra PM, Bate M. 2002. Regulation of synaptic connectivity: Levels of Fasciclin II influence synaptic growth in the Drosophila CNS. J Neurosci 22: 6587-6595.

Bao S, Cagan R. 2005. Preferential adhesion mediated by Hibris and Roughest regulates morphogenesis and patterning in the Drosophila eye. Dev Cell 8: 925-935.

Bateman A, Jouet M, MacFarlane J, Du JS, Kenwrick S, Chothia C. 1996. Outline structure of the human L1 cell adhesion molecule and the sites where mutations cause neurological disorders. Embo J 15: 6050-6059.

Baumgartner S, Littleton JT, Broadie K, Bhat MA, Harbecke R, Lengyel JA, Chiquet-Ehrismann R, Prokop A, Bellen HJ. 1996. A Drosophila neurexin is required for septate junction and blood-nerve barrier formation and function. Cell 87: 1059-1068.

Bazigou E, Apitz H, Johansson J, Loren CE, Hirst EM, Chen PL, Palmer RH, Salecker I. 2007. Anterograde Jelly belly and Alk receptor tyrosine kinase signaling mediates retinal axon targeting in Drosophila. Cell 128: 961-975.

Bekirov IH, Needleman LA, Zhang W, Benson DL. 2002. Identification and localization of multiple classic cadherins in developing rat limbic system. Neuroscience 115: 213-227.

Benson DL, Tanaka H. 1998. N-cadherin redistribution during synaptogenesis in hippocampal neurons. Neurosci 18: 6892-6904.

Bhat MA, Rios JC, Lu Y, Garcia-Fresco GP, Ching W, St Martin M, Li J, Einheber S, Chesler M, Rosenbluth J, et al. 2001. Axon-glia interactions and the domain organization of myelinated axons requires neurexin IV/Caspr/ Paranodin. Neuron 30: 369-383.

Bieber AJ, Snow PM, Hortsch M, Patel NH, Jacobs JR, Traquina ZR, Schilling J, Goodman CS. 1989. Drosophila neuroglian: A member of the immunoglobulin superfamily with extensive homology to the vertebrate neural adhesion molecule L1. Cell 59: 447-460.

Biederer T. 2006. Bioinformatic characterization of the SynCAM family of immunoglobulin-like domaincontaining adhesion molecules. Genomics 87: 139-150.

Biederer T, Scheiffele P. 2007. Mixed-culture assays for analyzing neuronal synapse formation. Nat Protoc 2: $670-676$.

Biederer T, Stagi M. 2008. Signaling by synaptogenic molecules. Curr Opin Neurobiol 18: 261-269.
Biederer T, Sudhof TC. 2000. Mints as adaptors. Direct binding to neurexins and recruitment of munc18. J Biol Chem 275: 39803-39806.

Biederer T, Sara Y, Mozhayeva M, Atasoy D, Liu X, Kavalali ET, Sudhof TC. 2002. SynCAM, a synaptic adhesion molecule that drives synapse assembly. Science 297: 1525-1531.

Bier E. 2005. Drosophila, the golden bug, emerges as a tool for human genetics. Nat Rev Genet 6: 9-23.

Bolliger MF, Frei K, Winterhalter KH, Gloor SM. 2001. Identification of a novel neuroligin in humans which binds to PSD-95 and has a widespread expression. Biochem J 356: 581-588.

Boucard AA, Chubykin AA, Comoletti D, Taylor P, Sudhof TC. 2005. A splice code for trans-synaptic cell adhesion mediated by binding of neuroligin 1 to $\alpha$ - and $\beta$-neurexins. Neuron 48: 229-236.

Bour BA, Chakravarti M, West JM, Abmayr SM. 2000. Drosophila SNS, a member of the immunoglobulin superfamily that is essential for myoblast fusion. Genes \& Dev 14: 1498-1511.

Buchert M, Schneider S, Meskenaite V, Adams MT, Canaani E, Baechi T, Moelling K, Hovens CM. 1999. The junction-associated protein AF-6 interacts and clusters with specific Eph receptor tyrosine kinases at specialized sites of cell-cell contact in the brain. J Cell Biol 144: 361-371.

Budnik V, Zhong Y, Wu CF. 1990. Morphological plasticity of motor axons in Drosophila mutants with altered excitability. J Neurosci 10: 3754-3768.

Budreck EC, Scheiffele P. 2007. Neuroligin-3 is a neuronal adhesion protein at GABAergic and glutamatergic synapses. Eur J Neurosci 26: 1738-1748.

Bukalo O, Fentrop N, Lee AY, Salmen B, Law JW, Wotjak CT, Schweizer M, Dityatev A, Schachner M. 2004. Conditional ablation of the neural cell adhesion molecule reduces precision of spatial learning, long-term potentiation, and depression in the CA1 subfield of mouse hippocampus. J Neurosci 24: 1565-1577.

Burmeister M, McInnis MG, Zollner S. 2008. Psychiatric genetics: Progress amid controversy. Nat Rev Genet 9: 527-540.

Butz S, Okamoto M, Sudhof TC. 1998. A tripartite protein complex with the potential to couple synaptic vesicle exocytosis to cell adhesion in brain. Cell 94: 773-782.

Carroll P, Gayet O, Feuillet C, Kallenbach S, de Bovis B, Dudley K, Alonso S. 2001. Juxtaposition of CNR protocadherins and reelin expression in the developing spinal cord. Mol Cell Neurosci 17: 611-623.

Carthew RW. 2005. Adhesion proteins and the control of cell shape. Curr Opin Genet Dev 15: 358-363.

Carthew RW. 2007. Pattern formation in the Drosophila eye. Curr Opin Genet Dev 17: 309-313.

Chao DL, Shen K. 2008. Functional dissection of SYG-1 and SYG-2, cell adhesion molecules required for selective synaptogenesis in C. elegans. Mol Cell Neurosci 39: $248-257$.

Chen PL, Clandinin TR. 2008. The cadherin Flamingo mediates level-dependent interactions that guide photoreceptor target choice in Drosophila. Neuron 58: 26-33. 
Cheng Y, Endo K, Wu K, Rodan AR, Heberlein U, Davis RL. 2001. Drosophila fasciclinII is required for the formation of odor memories and for normal sensitivity to alcohol. Cell 105: 757-768.

Cheng L, Itoh K, Lemmon V. 2005. L1-mediated branching is regulated by two ezrin-radixin-moesin (ERM)-binding sites, the RSLE region and a novel juxtamembrane ERM-binding region. J Neurosci 25: 395-403.

Chih B, Afridi SK, Clark L, Scheiffele P. 2004. Disorderassociated mutations lead to functional inactivation of neuroligins. Hum Mol Genet 13: 1471-1477.

Chih B, Engelman H, Scheiffele P. 2005. Control of excitatory and inhibitory synapse formation by neuroligins. Science 307: 1324-1328.

Chih B, Gollan L, Scheiffele P. 2006. Alternative splicing controls selective trans-synaptic interactions of the neuroligin-neurexin complex. Neuron 51: 171-178.

Choe KM, Prakash S, Bright A, Clandinin TR. 2006. Liprin- $\alpha$ is required for photoreceptor target selection in Drosophila. Proc Natl Acad Sci 103: 11601-11606.

Clandinin TR, Lee CH, Herman T, Lee RC, Yang AY, Ovasapyan S, Zipursky SL. 2001. Drosophila LAR regulates R1-R6 and R7 target specificity in the visual system. Neuron 32: 237-248.

Cohen NR, Taylor JS, Scott LB, Guillery RW, Soriano P, Furley AJ. 1998. Errors in corticospinal axon guidance in mice lacking the neural cell adhesion molecule L1. Curr Biol 8: 26-33.

Colon-Ramos DA, Margeta MA, Shen K. 2007. Glia promote local synaptogenesis through UNC-6 (netrin) signaling in C. elegans. Science 318: 103-106.

Craig AM, Boudin H. 2001. Molecular heterogeneity of central synapses: Afferent and target regulation. Nat Neurosci 4: 569-578.

Craig AM, Kang Y. 2007. Neurexin-neuroligin signaling in synapse development. Curr Opin Neurobiol 17: 43-52.

Craig AM, Graf ER, Linhoff MW. 2006. How to build a central synapse: Clues from cell culture. Trends Neurosci 29: $8-20$.

Cremer H, Lange R, Christoph A, Plomann M, Vopper G, Roes J, Brown R, Baldwin S, Kraemer P, Scheff S, et al. 1994. Inactivation of the N-CAM gene in mice results in size reduction of the olfactory bulb and deficits in spatial learning. Nature 367: 455-459.

Cremer H, Chazal G, Lledo PM, Rougon G, Montaron MF, Mayo W, Le Moal M, Abrous DN. 2000. PSA-NCAM: An important regulator of hippocampal plasticity. Int $J$ Dev Neurosci 18: 213-220.

Crossin KL, Krushel LA. 2000. Cellular signaling by neural cell adhesion molecules of the immunoglobulin superfamily. Dev Dyn 218: 260-279.

Dahme M, Bartsch U, Martini R, Anliker B, Schachner M, Mantei N. 1997. Disruption of the mouse L1 gene leads to malformations of the nervous system. Nat Genet 17: 346-349.

Dalva MB. 2007. There's more than one way to skin a chimaerin. Neuron 55: 681-684.

Dalva MB, McClelland AC, Kayser MS. 2007. Cell adhesion molecules: Signalling functions at the synapse. Nat Rev Neurosci 8: 206-220.
Davis JQ, Bennett V. 1994. Ankyrin binding activity shared by the neurofascin/L1/NrCAM family of nervous system cell adhesion molecules. J Biol Chem 269: 27163-27166.

Davis GW, Schuster CM, Goodman CS. 1997. Genetic analysis of the mechanisms controlling target selection: Target-derived Fasciclin II regulates the pattern of synapse formation. Neuron 19: 561-573.

De Angelis E, Watkins A, Schafer M, Brummendorf T, Kenwrick S. 2002. Disease-associated mutations in L1 CAM interfere with ligand interactions and cell-surface expression. Hum Mol Genet 11: 1-12.

Dean C, Dresbach T. 2006. Neuroligins and neurexins: Linking cell adhesion, synapse formation and cognitive function. Trends Neurosci 29: 21-29.

Dean C, Scholl FG, Choih J, DeMaria S, Berger J, Isacoff E, Scheiffele P. 2003. Neurexin mediates the assembly of presynaptic terminals. Nat Neurosci 6: 708-716.

Demyanenko GP, Tsai AY, Maness PF. 1999. Abnormalities in neuronal process extension, hippocampal development, and the ventricular system of L1 knockout mice. J Neurosci 19: 4907-4920.

Demyanenko GP, Shibata Y, Maness PF. 2001. Altered distribution of dopaminergic neurons in the brain of L1 null mice. Brain Res Dev Brain Res 126: 21-30.

Dickson TC, Mintz CD, Benson DL, Salton SR. 2002. Functional binding interaction identified between the axonal CAM L1 and members of the ERM family. J Cell Biol 157: 1105-1112.

Ding M, Chao D, Wang G, Shen K. 2007. Spatial regulation of an E3 ubiquitin ligase directs selective synapse elimination. Science 317: 947-951.

Dityatev A, Dityateva G, Schachner M. 2000. Synaptic strength as a function of post- versus presynaptic expression of the neural cell adhesion molecule NCAM. Neuron 26: 207-217.

Dityatev A, Dityateva G, Sytnyk V, Delling M, Toni N, Nikonenko I, Muller D, Schachner M. 2004. Polysialylated neural cell adhesion molecule promotes remodeling and formation of hippocampal synapses. J Neurosci 24: 9372-9382.

Dudanova I, Tabuchi K, Rohlmann A, Sudhof TC, Missler M. 2007. Deletion of $\alpha$-neurexins does not cause a major impairment of axonal pathfinding or synapse formation. J Comp Neurol 502: 261-274.

Dunah AW, Hueske E, Wyszynski M, Hoogenraad CC, Jaworski J, Pak DT, Simonetta A, Liu G, Sheng M. 2005. LAR receptor protein tyrosine phosphatases in the development and maintenance of excitatory synapses. Nat Neurosci 8: 458-467.

Durand CM, Betancur C, Boeckers TM, Bockmann J, Chaste P, Fauchereau F, Nygren G, Rastam M, Gillberg IC Anckarsater H, et al. 2007. Mutations in the gene encoding the synaptic scaffolding protein SHANK3 are associated with autism spectrum disorders. Nat Genet 39: 25-27.

Dworak HA, Sink H. 2002. Myoblast fusion in Drosophila. Bioessays 24: 591-601.

Dworak HA, Charles MA, Pellerano LB, Sink H. 2001. Characterization of Drosophila hibris, a gene related to human nephrin. Development 128: 4265-4276. 
Eaton BA, Davis GW. 2003. Synapse disassembly. Genes \& Dev 17: 2075-2082.

Eckhardt M, Bukalo O, Chazal G, Wang L, Goridis C, Schachner M, Gerardy-Schahn R, Cremer H, Dityatev A. 2000. Mice deficient in the polysialyltransferase ST8SiaIV/PST-1 allow discrimination of the roles of neural cell adhesion molecule protein and polysialic acid in neural development and synaptic plasticity. $J$ Neurosci 20: 5234-5244.

Elia LP, Yamamoto M, Zang K, Reichardt LF. 2006. p120 catenin regulates dendritic spine and synapse development through Rho-family GTPases and cadherins. Neuron 51: 43-56.

Fannon AM, Colman DR. 1996. A model for central synaptic junctional complex formation based on the differential adhesive specificities of the cadherins. Neuron 17: 423-434.

Feinberg EH, Vanhoven MK, Bendesky A, Wang G, Fetter RD, Shen K, Bargmann CI. 2008. GFP Reconstitution Across Synaptic Partners (GRASP) defines cell contacts and synapses in living nervous systems. Neuron 57: 353-363.

Fogel AI, Akins MR, Krupp AJ, Stagi M, Stein V, Biederer T. 2007. SynCAMs organize synapses through heterophilic adhesion. J Neurosci 27: 12516-12530.

Frank M, Kemler R. 2002. Protocadherins. Curr Opin Cell Biol 14: 557-562.

Fransen E, Lemmon V, Van Camp G, Vits L, Coucke P, Willems PJ. 1995. CRASH syndrome: Clinical spectrum of corpus callosum hypoplasia, retardation, adducted thumbs, spastic paraparesis and hydrocephalus due to mutations in one single gene, L1. Eur J Hum Genet 3: $273-284$.

Fransen E, Van Camp G, Vits L, Willems PJ. 1997. L1-associated diseases: Clinical geneticists divide, molecular geneticists unite. Hum Mol Genet 6: $1625-$ 32.

Fransen E, Van Camp G, D’Hooge R, Vits L, Willems PJ. 1998. Genotype-phenotype correlation in L1 associated diseases. J Med Genet 35: 399-404.

Fujita E, Kouroku Y, Ozeki S, Tanabe Y, Toyama Y, Maekawa M, Kojima N, Senoo H, Toshimori K, Momoi T. 2006. Oligo-astheno-teratozoospermia in mice lacking RA175/TSLC1/SynCAM/IGSF4A, a cell adhesion molecule in the immunoglobulin superfamily. Mol Cell Biol 26: $718-726$.

Gao FB, Brenman JE, Jan LY, Jan YN. 1999. Genes regulating dendritic outgrowth, branching, and routing in Drosophila. Genes \& Dev 13: 2549-2561.

Gao FB, Kohwi M, Brenman JE, Jan LY, Jan YN. 2000. Control of dendritic field formation in Drosophila: The roles of flamingo and competition between homologous neurons. Neuron 28: 91-101.

Garcia-Alonso L, Romani S, Jimenez F. 2000. The EGF and FGF receptors mediate neuroglian function to control growth cone decisions during sensory axon guidance in Drosophila. Neuron 28: 741-752.

Garner CC, Waites CL, Ziv NE. 2006. Synapse development: Still looking for the forest, still lost in the trees. Cell Tissue Res 326: 249-262.
Gerke P, Benzing T, Hohne M, Kispert A, Frotscher M, Walz G, Kretz O. 2006. Neuronal expression and interaction with the synaptic protein CASK suggest a role for Neph1 and Neph2 in synaptogenesis. J Comp Neurol 498: 466-475.

Gerrow K, El-Husseini A. 2006. Cell adhesion molecules at the synapse. Front Biosci 11: 2400-2419.

Geschwind DH. 2008. Autism: Many genes, common pathways? Cell 135: 391-395.

Geschwind DH, Levitt P. 2007. Autism spectrum disorders: Developmental disconnection syndromes. Curr Opin Neurobiol 17: 103-111.

Goda Y, Davis GW. 2003. Mechanisms of synapse assembly and disassembly. Neuron 40: 243-64.

Godenschwege TA, Kristiansen LV, Uthaman SB, Hortsch M, Murphey RK. 2006. A conserved role for Drosophila Neuroglian and human L1-CAM in central-synapse formation. Curr Biol 16: 12-23.

Gottmann K. 2008. Transsynaptic modulation of the synaptic vesicle cycle by cell-adhesion molecules. J Neurosci Res 86: $223-232$.

Graf ER, Zhang X, Jin SX, Linhoff MW, Craig AM. 2004. Neurexins induce differentiation of GABA and glutamate postsynaptic specializations via neuroligins. Cell 119: 1013-1026.

Grueber WB, Jan LY, Jan YN. 2002. Tiling of the Drosophila epidermis by multidendritic sensory neurons. Development 129: 2867-2878.

Haass C, Selkoe DJ. 2007. Soluble protein oligomers in neurodegeneration: Lessons from the Alzheimer's amyloid $\beta$-peptide. Nat Rev Mol Cell Biol 8: 101-112.

Hall SG, Bieber AJ. 1997. Mutations in the Drosophila neuroglian cell adhesion molecule affect motor neuron pathfinding and peripheral nervous system patterning. J Neurobiol 32: 325-340.

Hata Y, Butz S, Sudhof TC. 1996. CASK: A novel dlg/PSD95 homolog with an N-terminal calmodulin-dependent protein kinase domain identified by interaction with neurexins. J Neurosci 16: 2488-2494.

Hirano S, Wang X, Suzuki ST. 2002. Restricted expression of protocadherin $2 \mathrm{~A}$ in the developing mouse brain. Brain Res Mol Brain Res 98: 119-123.

Hock B, Bohme B, Karn T, Yamamoto T, Kaibuchi K, Holtrich U, Holland S, Pawson T, RubsamenWaigmann H, Strebhardt K. 1998. PDZ-domainmediated interaction of the Eph-related receptor tyrosine kinase EphB3 and the ras-binding protein AF6 depends on the kinase activity of the receptor. Proc Natl Acad Sci 95: 9779-9784.

Hofmeyer K, Maurel-Zaffran C, Sink H, Treisman JE. 2006. Liprin- $\alpha$ has LAR-independent functions in R7 photoreceptor axon targeting. Proc Natl Acad Sci 103: 11595-11600.

Honda T, Shimizu K, Kawakatsu T, Fukuhara A, Irie K, Nakamura T, Matsuda M, Takai Y. 2003. Cdc42 and Rac small $G$ proteins activated by trans-interactions of nectins are involved in activation of c-Jun $\mathrm{N}$-terminal kinase, but not in association of nectins and cadherin to form adherens junctions, in fibroblasts. Genes Cells 8: $481-491$. 
Honda T, Sakisaka T, Yamada T, Kumazawa N, Hoshino T, Kajita M, Kayahara T, Ishizaki H, Tanaka-Okamoto M, Mizoguchi A, et al. 2006. Involvement of nectins in the formation of puncta adherentia junctions and the mossy fiber trajectory in the mouse hippocampus. $\mathrm{Mol}$ Cell Neurosci 31: 315-325.

Hoogenraad CC, Feliu-Mojer MI, Spangler SA, Milstein AD, Dunah AW, Hung AY, Sheng M. 2007. Liprinal degradation by calcium/calmodulin-dependent protein kinase II regulates LAR receptor tyrosine phosphatase distribution and dendrite development. Dev Cell 12: 587-602.

Hortsch M, Bieber AJ, Patel NH, Goodman CS. 1990. Differential splicing generates a nervous system-specific form of Drosophila neuroglian. Neuron 4: 697-709.

Hortsch M, Nagaraj K, Godenschwege TA. 2009. The interaction between L1-type proteins and ankyrins-a master switch for L1-type CAM function. Cell Mol Biol Lett 14: 57-69.

Hulpiau P, van Roy F. 2009. Molecular evolution of the cadherin superfamily. Int J Biochem Cell Biol 41: 349-369.

Hummel T, Zipursky SL. 2004. Afferent induction of olfactory glomeruli requires N-cadherin. Neuron 42: 77-88.

Ichtchenko K, Nguyen T, Sudhof TC. 1996. Structures, alternative splicing, and neurexin binding of multiple neuroligins. J Biol Chem 271: 2676-2682.

Ikeda W, Nakanishi H, Miyoshi J, Mandai K, Ishizaki H, Tanaka M, Togawa A, Takahashi K, Nishioka $\mathrm{H}$ Yoshida H, et al. 1999. Afadin: A key molecule essential for structural organization of cell-cell junctions of polarized epithelia during embryogenesis. J Cell Biol 146: 1117-1132.

Inlow JK, Restifo LL. 2004. Molecular and comparative genetics of mental retardation. Genetics 166: $835-881$.

Inoue T, Tanaka T, Suzuki SC, Takeichi M. 1998. Cadherin-6 in the developing mouse brain: Expression along restricted connection systems and synaptic localization suggest a potential role in neuronal circuitry. Dev Dyn 211: 338-351.

Iwai Y, Usui T, Hirano S, Steward R, Takeichi M, Uemura T 1997. Axon patterning requires DN-cadherin, a novel neuronal adhesion receptor, in the Drosophila embryonic CNS. Neuron 19: 77-89.

Jin Y, Garner CC. 2008. Molecular mechanisms of presynaptic differentiation. Annu Rev Cell Dev Biol 24: 237-262.

Johnson KG, Tenney AP, Ghose A, Duckworth AM, Higashi ME, Parfitt K, Marcu O, Heslip TR, Marsh JL, Schwarz TL, et al. 2006. The HSPGs Syndecan and Dallylike bind the receptor phosphatase LAR and exert distinct effects on synaptic development. Neuron 49: 517-531.

Jontes JD, Emond MR, Smith SJ. 2004. In vivo trafficking and targeting of $\mathrm{N}$-cadherin to nascent presynaptic terminals. J Neurosci 24: 9027-9034.

Jungling K, Eulenburg V, Moore R, Kemler R, Lessmann V, Gottmann K. 2006. N-cadherin transsynaptically regulates short-term plasticity at glutamatergic synapses in embryonic stem cell-derived neurons. J Neurosci 26: 6968-6978.

Kattenstroth G, Tantalaki E, Sudhof TC, Gottmann K, Missler M. 2004. Postsynaptic N-methyl-D-aspartate receptor function requires $\alpha$-neurexins. Proc Natl Acad Sci 101: 2607-2612.

Kaufmann N, DeProto J, Ranjan R, Wan H, Van Vactor D. 2002. Drosophila liprin- $\alpha$ and the receptor phosphatase Dlar control synapse morphogenesis. Neuron 34: 27-38.

Kenwrick S, Doherty P. 1998. Neural cell adhesion molecule L1: Relating disease to function. Bioessays 20: 668-675.

Kenwrick S, Watkins A, De Angelis E. 2000. Neural cell recognition molecule L1: Relating biological complexity to human disease mutations. Hum Mol Genet 9: 879-886.

Kim S, Burette A, Chung HS, Kwon SK, Woo J, Lee HW, Kim K, Kim H, Weinberg RJ, Kim E. 2006. NGL family PSD-95-interacting adhesion molecules regulate excitatory synapse formation. Nat Neurosci 9: 1294-1301.

Kizhatil K, Wu YX, Sen A, Bennett V. 2002. A new activity of doublecortin in recognition of the phospho-FIGQY tyrosine in the cytoplasmic domain of neurofascin. J Neurosci 22: 7948-7958.

Ko J, Kim E. 2007. Leucine-rich repeat proteins of synapses. J Neurosci Res 85: 2824-2832.

Ko J, Na M, Kim S, Lee JR, Kim E. 2003. Interaction of the ERC family of RIM-binding proteins with the liprin- $\alpha$ family of multidomain proteins. J Biol Chem 278: 42377-42385.

Ko J, Kim S, Chung HS, Kim K, Han K, Kim H, Jun H, Kaang BK, Kim E. 2006. SALM synaptic cell adhesion-like molecules regulate the differentiation of excitatory synapses. Neuron 50: 233-245.

Koch I, Schwarz H, Beuchle D, Goellner B, Langegger M, Aberle H. 2008. Drosophila ankyrin 2 is required for synaptic stability. Neuron 58: 210-222.

Koh YH, Popova E, Thomas U, Griffith LC, Budnik V. 1999. Regulation of DLG localization at synapses by CaMKII-dependent phosphorylation. Cell 98: 353-363.

Kohmura N, Senzaki K, Hamada S, Kai N, Yasuda R, Watanabe M, Ishii $\mathrm{H}$, Yasuda M, Mishina M, Yagi T. 1998. Diversity revealed by a novel family of cadherins expressed in neurons at a synaptic complex. Neuron 20: 1137-1151.

Kramer JM, van Bokhoven H. 2009. Genetic and epigenetic defects in mental retardation. Int J Biochem Cell Biol 41: 96-107.

Krey JF, Dolmetsch RE. 2007. Molecular mechanisms of autism: A possible role for $\mathrm{Ca} 2+$ signaling. Curr Opin Neurobiol 17: 112-119.

Kristiansen LV, Hortsch M. 2008. Fasciclin II: The NCAM Ortholog in Drosophila melanogaster. Neurochem Res. Doi: 10.1007/s11064-007-9566-9568.

Kristiansen LV, Velasquez E, Romani S, Baars S, Berezin V, Bock E, Hortsch M, Garcia-Alonso L. 2005. Genetic analysis of an overlapping functional requirement for L1- and NCAM-type proteins during sensory axon guidance in Drosophila. Mol Cell Neurosci 28: 141-152.

Kurusu M, Cording A, Taniguchi M, Menon K, Suzuki E, Zinn K. 2008. A screen of cell-surface molecules identifies leucine-rich repeat proteins as key mediators of synaptic target selection. Neuron 59: 972-985.

Law JW, Lee AY, Sun M, Nikonenko AG, Chung SK, Dityatev A, Schachner M, Morellini F. 2003. Decreased anxiety, altered place learning, and increased CA1 basal excitatory synaptic transmission in mice with conditional ablation 
of the neural cell adhesion molecule L1. J Neurosci 23: 10419-10432.

Lee CH, Herman T, Clandinin TR, Lee R, Zipursky SL. 2001. $\mathrm{N}$-cadherin regulates target specificity in the Drosophila visual system. Neuron 30: 437-450.

Lee RC, Clandinin TR, Lee CH, Chen PL, Meinertzhagen IA, Zipursky SL. 2003. The protocadherin Flamingo is required for axon target selection in the Drosophila visual system. Nat Neurosci 6: 557-563.

Li J, Ashley J, Budnik V, Bhat MA. 2007. Crucial role of Drosophila neurexin in proper active zone apposition to postsynaptic densities, synaptic growth, and synaptic transmission. Neuron 55: 741-755.

Lin JC, Ho WH, Gurney A, Rosenthal A. 2003. The netrin-G1 ligand NGL-1 promotes the outgrowth of thalamocortical axons. Nat Neurosci 6: 1270-1276.

Lu B, Usui T, Uemura T, Jan L, Jan YN. 1999. Flamingo controls the planar polarity of sensory bristles and asymmetric division of sensory organ precursors in Drosophila. Curr Biol 9: 1247-1250.

Maness PF, Schachner M. 2007. Neural recognition molecules of the immunoglobulin superfamily: Signaling transducers of axon guidance and neuronal migration. Nat Neurosci 10: 19-26.

Martin V, Mrkusich E, Steinel MC, Rice J, Merritt DJ, Whitington PM. 2008. The L1-type cell adhesion molecule Neuroglian is necessary for maintenance of sensory axon advance in the Drosophila embryo. Neural Develop 3: 10.

Masai I, Lele Z, Yamaguchi M, Komori A, Nakata A, Nishiwaki Y, Wada H, Tanaka H, Nojima Y, Hammerschmidt M, et al. 2003. N-cadherin mediates retinal lamination, maintenance of forebrain compartments and patterning of retinal neurites. Development 130: $2479-2494$

Mast JD, Prakash S, Chen PL, Clandinin TR. 2006. The mechanisms and molecules that connect photoreceptor axons to their targets in Drosophila. Semin Cell Dev Biol 17: $42-49$.

Maurel-Zaffran C, Suzuki T, Gahmon G, Treisman JE, Dickson BJ. 2001. Cell-autonomous and -nonautonomous functions of LAR in R7 photoreceptor axon targeting. Neuron 32: 225-235.

McAllister AK. 2007. Dynamic aspects of CNS synapse formation. Annu Rev Neurosci 30: 425-450.

Miller KE, DeProto J, Kaufmann N, Patel BN, Duckworth A, Van Vactor D. 2005. Direct observation demonstrates that Liprin- $\alpha$ is required for trafficking of synaptic vesicles. Curr Biol 15: 684-689.

Miskevich F, Zhu Y, Ranscht B, Sanes JR. 1998. Expression of multiple cadherins and catenins in the chick optic tectum. Mol Cell Neurosci 12: 240-255.

Missler M. 2003. Synaptic cell adhesion goes functional. Trends Neurosci 26: 176-178.

Missler M, Zhang W, Rohlmann A, Kattenstroth G, Hammer RE, Gottmann K, Sudhof TC. 2003. $\alpha$-neurexins couple $\mathrm{Ca} 2+$ channels to synaptic vesicle exocytosis. Nature 423: 939-948.

Mizoguchi A, Nakanishi H, Kimura K, Matsubara K, Ozaki-Kuroda K, Katata T, Honda T, Kiyohara Y, Heo K, Higashi M, et al. 2002. Nectin: An adhesion molecule involved in formation of synapses. J Cell Biol 156: 555-565.

Morishita H, Yagi T. 2007. Protocadherin family: Diversity, structure, and function. Curr Opin Cell Biol 19: 584-592.

Muller D, Wang C, Skibo G, Toni N, Cremer H, Calaora V, Rougon G, Kiss JZ. 1996. PSA-NCAM is required for activity-induced synaptic plasticity. Neuron 17: 413-422.

Nam CI, Chen L. 2005. Postsynaptic assembly induced by neurexin-neuroligin interaction and neurotransmitter. Proc Natl Acad Sci 102: 6137-6142.

Nern A, Nguyen LV, Herman T, Prakash S, Clandinin TR, Zipursky SL. 2005. An isoform-specific allele of Drosophila N-cadherin disrupts a late step of R7 targeting. Proc Natl Acad Sci 102: 12944-12949.

Nern A, Zhu Y, Zipursky SL. 2008. Local N-cadherin interactions mediate distinct steps in the targeting of lamina neurons. Neuron 58: 34-41.

Newsome TP, Asling B, Dickson BJ. 2000. Analysis of Drosophila photoreceptor axon guidance in eye-specific mosaics. Development 127: 851-860.

Nollet F, Kools P, van Roy F. 2000. Phylogenetic analysis of the cadherin superfamily allows identification of six major subfamilies besides several solitary members. J Mol Biol 299: 551-572.

Nuriya M, Huganir RL. 2006. Regulation of AMPA receptor trafficking by N-cadherin. J Neurochem 97: 652-661.

Ohtsuka T, Takao-Rikitsu E, Inoue E, Inoue M, Takeuchi M, Matsubara K, Deguchi-Tawarada M, Satoh K, Morimoto K, Nakanishi H, et al. 2002. Cast: A novel protein of the cytomatrix at the active zone of synapses that forms a ternary complex with RIM1 and munc13-1. J Cell Biol 158: $577-590$.

Okamura K, Tanaka H, Yagita Y, Saeki Y, Taguchi A, Hiraoka Y, Zeng LH, Colman DR, Miki N. 2004. Cadherin activity is required for activity-induced spine remodeling. J Cell Biol 167: 961-972.

Okuda T, Yu LM, Cingolani LA, Kemler R, Goda Y. 2007. $\beta$-Catenin regulates excitatory postsynaptic strength at hippocampal synapses. Proc Natl Acad Sci 104: 13479-13484.

Olsen O, Moore KA, Fukata M, Kazuta T, Trinidad JC, Kauer FW, Streuli M, Misawa H, Burlingame AL, Nicoll RA, et al. 2005. Neurotransmitter release regulated by a MALS-liprin- $\alpha$ presynaptic complex. J Cell Biol 170: 1127-1134.

Ooshio T, Irie K, Morimoto K, Fukuhara A, Imai T, Takai Y. 2004. Involvement of $\mathrm{LMO} 7$ in the association of two cell-cell adhesion molecules, nectin and E-cadherin, through afadin and $\alpha$-actinin in epithelial cells. J Biol Chem 279: 31365-31373.

Packard M, Mathew D, Budnik V. 2003. FASt remodeling of synapses in Drosophila. Curr Opin Neurobiol 13: 527-534.

Patel MR, Lehrman EK, Poon VY, Crump JG, Zhen M, Bargmann CI, Shen K. 2006. Hierarchical assembly of presynaptic components in defined C. elegans synapses. Nat Neurosci 9: 1488-98.

Patrakka J, Tryggvason K. 2007. Nephrin-a unique structural and signaling protein of the kidney filter. Trends Mol Med 13: 396-403. 
Phillips GR, Tanaka H, Frank M, Elste A, Fidler L, Benson DL, Colman DR. 2003. $\gamma$-protocadherins are targeted to subsets of synapses and intracellular organelles in neurons. J Neurosci 23: 5096-5104.

Piechotta K, Dudanova I, Missler M. 2006. The resilient synapse: Insights from genetic interference of synaptic cell adhesion molecules. Cell Tissue Res 326: 617-642.

Pielage J, Fetter RD, Davis GW. 2006. A postsynaptic spectrin scaffold defines active zone size, spacing, and efficacy at the Drosophila neuromuscular junction. J Cell Biol 175: 491-503.

Pielage J, Cheng L, Fetter RD, Carlton PM, Sedat JW, Davis GW. 2008. A presynaptic giant ankyrin stabilizes the NM] through regulation of presynaptic microtubules and transsynaptic cell adhesion. Neuron 58: 195-209.

Pokutta S, Weis WI. 2007. Structure and mechanism of cadherins and catenins in cell-cell contacts. Annu Rev Cell Dev Biol 23: 237-261.

Pokutta S, Drees F, Takai Y, Nelson WJ, Weis WI. 2002. Biochemical and structural definition of the 1-afadinand actin-binding sites of $\alpha$-catenin. J Biol Chem 277: $18868-18874$.

Polo-Parada L, Bose CM, Landmesser LT. 2001. Alterations in transmission, vesicle dynamics, and transmitter release machinery at NCAM-deficient neuromuscular junctions. Neuron 32: 815-828.

Prakash S, Caldwell JC, Eberl DF, Clandinin TR. 2005. Drosophila $\mathrm{N}$-cadherin mediates an attractive interaction between photoreceptor axons and their targets. Nat Neurosci 8: 443-450.

Ramocki MB, Zoghbi HY. 2008. Failure of neuronal homeostasis results in common neuropsychiatric phenotypes. Nature 455: 912-918.

Ramos RG, Igloi GL, Lichte B, Baumann U, Maier D, Schneider T, Brandstatter JH, Frohlich A, Fischbach KF 1993. The irregular chiasm C-roughest locus of Drosophila, which affects axonal projections and programmed cell death, encodes a novel immunoglobulinlike protein. Genes \& Dev 7: 2533-2547.

Ranscht B. 2000. Cadherins: Molecular codes for axon guidance and synapse formation. Int J Dev Neurosci 18: 643-651.

Redies C. 2000. Cadherins in the central nervous system. Prog Neurobiol 61: 611-48.

Redies C, Vanhalst K, Roy F. 2005. $\delta$-Protocadherins: Unique structures and functions. Cell Mol Life Sci 62: 2840-2852.

Ritzenthaler S, Suzuki E, Chiba A. 2000. Postsynaptic filopodia in muscle cells interact with innervating motoneuron axons. Nat Neurosci 3: 1012-1017.

Rudenko G, Nguyen T, Chelliah Y, Sudhof TC, Deisenhofer J. 1999. The structure of the ligand-binding domain of neurexin $I \beta$ : Regulation of LNS domain function by alternative splicing. Cell 99: 93-101.

Rudenko G, Hohenester E, Muller YA. 2001. LG/LNS domains: Multiple functions-one business end? Trends Biochem Sci 26: 363-368.

Ruiz-Gomez M, Coutts N, Price A, Taylor MV, Bate M. 2000. Drosophila dumbfounded: A myoblast attractant essential for fusion. Cell 102: 189-198.

Saghatelyan AK, Nikonenko AG, Sun M, Rolf B, Putthoff P, Kutsche M, Bartsch U, Dityatev A, Schachner M. 2004.
Cell Adhesion, the Backbone of the Synapse

Reduced GABAergic transmission and number of hippocampal perisomatic inhibitory synapses in juvenile mice deficient in the neural cell adhesion molecule L1. Mol Cell Neurosci 26: 191-203.

Saglietti L, Dequidt C, Kamieniarz K, Rousset MC, Valnegri P, Thoumine O, Beretta F, Fagni L, Choquet D, Sala C, et al. 2007. Extracellular interactions between GluR2 and N-cadherin in spine regulation. Neuron 54: 461-477.

Salinas PC. 2005. Signaling at the vertebrate synapse: New roles for embryonic morphogens? J Neurobiol 64: $435-445$.

Salinas PC, Zou Y. 2008. Wnt signaling in neural circuit assembly. Annu Rev Neurosci 31: 339-358.

Sara Y, Biederer T, Atasoy D, Chubykin A, Mozhayeva MG, Sudhof TC, Kavalali ET. 2005. Selective capability of SynCAM and neuroligin for functional synapse assembly. J Neurosci 25: 260-270.

Scheiffele P, Fan J, Choih J, Fetter R, Serafini T. 2000. Neuroligin expressed in nonneuronal cells triggers presynaptic development in contacting axons. Cell 101: 657-669.

Schoch S, Castillo PE, Jo T, Mukherjee K, Geppert M, Wang Y, Schmitz F, Malenka RC, Sudhof TC. 2002. RIM1a forms a protein scaffold for regulating neurotransmitter release at the active zone. Nature 415: 321-326.

Schuster CM, Davis GW, Fetter RD, Goodman CS. 1996a. Genetic dissection of structural and functional components of synaptic plasticity. I. Fasciclin II controls synaptic stabilization and growth. Neuron 17: 641-654.

Schuster CM, Davis GW, Fetter RD, Goodman CS. 1996b. Genetic dissection of structural and functional components of synaptic plasticity. II. Fasciclin II controls presynaptic structural plasticity. Neuron 17: 655-667.

Schuster T, Krug M, Hassan H, Schachner M. 1998. Increase in proportion of hippocampal spine synapses expressing neural cell adhesion molecule NCAM180 following longterm potentiation. J Neurobiol 37: 359-372.

Seabold GK, Wang PY, Chang K, Wang CY, Wang YX, Petralia RS, Wenthold RJ. 2008. The SALM family of adhesion-like molecules forms heteromeric and homomeric complexes. J Biol Chem 283: 8395-8405.

Senti KA, Usui T, Boucke K, Greber U, Uemura T, Dickson BJ. 2003. Flamingo regulates R8 axon-axon and axontarget interactions in the Drosophila visual system. Curr Biol 13: 828-832.

Serafini T. 1999. Finding a partner in a crowd: Neuronal diversity and synaptogenesis. Cell 98: 133-136.

Shapiro L, Colman DR. 1999. The diversity of cadherins and implications for a synaptic adhesive code in the CNS. Neuron 23: 427-430.

Shapiro EM, Gonzalez-Perez O, Manuel Garcia-Verdugo J, Alvarez-Buylla A, Koretsky AP. 2006. Magnetic resonance imaging of the migration of neuronal precursors generated in the adult rodent brain. Neuroimage 32: $1150-1157$.

Shapiro L, Love J, Colman DR. 2007. Adhesion molecules in the nervous system: Structural insights into function and diversity. Annu Rev Neurosci 30: 451-474. 
Shen K, Bargmann CI. 2003. The immunoglobulin superfamily protein SYG-1 determines the location of specific synapses in C. elegans. Cell 112: 619-630.

Shen K, Fetter RD, Bargmann CI. 2004. Synaptic specificity is generated by the synaptic guidepost protein SYG-2 and its receptor, SYG-1. Cell 116: $869-881$.

Shima Y, Kengaku M, Hirano T, Takeichi M, Uemura T 2004. Regulation of dendritic maintenance and growth by a mammalian 7-pass transmembrane cadherin. Dev Cell 7: 205-216.

Shin H, Wyszynski M, Huh KH, Valtschanoff JG, Lee JR, Ko J, Streuli M, Weinberg RJ, Sheng M, Kim E. 2003. Association of the kinesin motor KIF1A with the multimodular protein liprin- $\alpha$. J Biol Chem 278: 11393-11401.

Shinza-Kameda M, Takasu E, Sakurai K, Hayashi S, Nose A. 2006. Regulation of layer-specific targeting by reciprocal expression of a cell adhesion molecule, capricious. Neuron 49: 205-13.

Shishido E, Takeichi M, Nose A. 1998. Drosophila synapse formation: Regulation by transmembrane protein with Leu-rich repeats, CAPRICIOUS. Science 280: 2118-2121.

Song JY, Ichtchenko K, Sudhof TC, Brose N. 1999. Neuroligin 1 is a postsynaptic cell-adhesion molecule of excitatory synapses. Proc Natl Acad Sci 96: 1100-1105.

Spangler SA, Hoogenraad CC. 2007. Liprin- $\alpha$ proteins: Scaffold molecules for synapse maturation. Biochem Soc Trans 35: 1278-1282.

Strunkelnberg M, Bonengel B, Moda LM, Hertenstein A, de Couet HG, Ramos RG, Fischbach KF. 2001. rst and its paralogue kirre act redundantly during embryonic muscle development in Drosophila. Development 128: 4229-4239.

Stryker E, Johnson KG. 2007. LAR, liprin $\alpha$ and the regulation of active zone morphogenesis. J Cell Sci 120: 3723-3728.

Sudhof TC. 2004. The synaptic vesicle cycle. Annu Rev Neurosci 27: 509-547.

Sudhof TC. 2008. Neuroligins and neurexins link synaptic function to cognitive disease. Nature 455: 903-911.

Suzuki SC, Inoue T, Kimura Y, Tanaka T, Takeichi M. 1997. Neuronal circuits are subdivided by differential expression of type-II classic cadherins in postnatal mouse brains. Mol Cell Neurosci 9: 433-447.

Tabuchi K, Sudhof TC. 2002. Structure and evolution of neurexin genes: Insight into the mechanism of alternative splicing. Genomics 79: 849-859.

Tachibana K, Nakanishi H, Mandai K, Ozaki K, Ikeda W, Yamamoto Y, Nagafuchi A, Tsukita S, Takai Y. 2000 Two cell adhesion molecules, nectin and cadherin, interact through their cytoplasmic domain-associated proteins. J Cell Biol 150: 1161-1176.

Tai CY, Mysore SP, Chiu C, Schuman EM. 2007. Activity-regulated N-cadherin endocytosis. Neuron 54: 771-785.

Tai CY, Kim SA, Schuman EM. 2008. Cadherins and synaptic plasticity. Curr Opin Cell Biol 20: 567-575.

Takai Y, Ikeda W, Ogita H, Rikitake Y. 2008a. The immunoglobulin-like cell adhesion molecule nectin and its associated protein afadin. Annu Rev Cell Dev Biol 24: 309-342.

Takai Y, Miyoshi J, Ikeda W, Ogita H. 2008b. Nectins and nectin-like molecules: Roles in contact inhibition of cell movement and proliferation. Nat Rev Mol Cell Biol 9: 603-615.

Takeichi M. 2007. The cadherin superfamily in neuronal connections and interactions. Nat Rev Neurosci 8: 11-20.

Tanabe K, Takahashi Y, Sato Y, Kawakami K, Takeichi M, Nakagawa S. 2006. Cadherin is required for dendritic morphogenesis and synaptic terminal organization of retinal horizontal cells. Development 133: 4085-4096.

Tanaka H, Shan W, Phillips GR, Arndt K, Bozdagi O, Shapiro L, Huntley GW, Benson DL, Colman DR. 2000. Molecular modification of $\mathrm{N}$-cadherin in response to synaptic activity. Neuron 25: 93-107.

Tang L, Hung CP, Schuman EM. 1998. A role for the cadherin family of cell adhesion molecules in hippocampal long-term potentiation. Neuron 20: 1165-1175.

Taniguchi H, Gollan L, Scholl FG, Mahadomrongkul V, Dobler E, Limthong N, Peck M, Aoki C, Scheiffele P. 2007. Silencing of neuroligin function by postsynaptic neurexins. J Neurosci 27: 2815-2824.

Tepass U, Harris KP. 2007. Adherens junctions in Drosophila retinal morphogenesis. Trends Cell Biol 17: 26-35.

Thomas U, Kim E, Kuhlendahl S, Koh YH, Gundelfinger ED, Sheng M, Garner CC, Budnik V. 1997. Synaptic clustering of the cell adhesion molecule fasciclin II by discs-large and its role in the regulation of presynaptic structure. Neuron 19: 787-799.

Thomas LA, Akins MR, Biederer T. 2008. Expression and adhesion profiles of SynCAM molecules indicate distinct neuronal functions. J Comp Neurol 510: $47-67$.

Ting CY, Lee CH. 2007. Visual circuit development in Drosophila. Curr Opin Neurobiol 17: 65-72.

Ting CY, Yonekura S, Chung P, Hsu SN, Robertson HM, Chiba A, Lee CH. 2005. Drosophila N-cadherin functions in the first stage of the two-stage layer-selection process of R7 photoreceptor afferents. Development 132: 953-963.

Tissir F, Bar I, Jossin Y, De Backer O, Goffinet AM. 2005. Protocadherin Celsr3 is crucial in axonal tract development. Nat Neurosci 8: 451-457.

Togashi H, Miyoshi J, Honda T, Sakisaka T, Takai Y, Takeichi M. 2006. Interneurite affinity is regulated by heterophilic nectin interactions in concert with the cadherin machinery. J Cell Biol 174: 141-151.

Uchida N, Honjo Y, Johnson KR, Wheelock MJ, Takeichi M. 1996. The catenin/cadherin adhesion system is localized in synaptic junctions bordering transmitter release zones. J Cell Biol 135: 767-779.

Ullrich B, Ushkaryov YA, Sudhof TC. 1995. Cartography of neurexins: More than 1000 isoforms generated by alternative splicing and expressed in distinct subsets of neurons. Neuron 14: 497-507.

Uryu K, Butler AK, Chesselet MF. 1999. Synaptogenesis and ultrastructural localization of the polysialylated neural cell adhesion molecule in the developing striatum. J Comp Neurol 405: 216-232. 
Ushkaryov YA, Petrenko AG, Geppert M, Sudhof TC. 1992. Neurexins: Synaptic cell surface proteins related to the $\alpha$-latrotoxin receptor and laminin. Science 257: 50-56.

van der Weyden L, Arends MJ, Chausiaux OE, Ellis PJ, Lange UC, Surani MA, Affara N, Murakami Y, Adams DJ, Bradley A. 2006. Loss of TSLC1 causes male infertility due to a defect at the spermatid stage of spermatogenesis. Mol Cell Biol 26: 3595-3609.

van Roessel P, Elliott DA, Robinson IM, Prokop A, Brand AH. 2004. Independent regulation of synaptic size and activity by the anaphase-promoting complex. Cell 119: 707-718.

Varoqueaux F, Jamain S, Brose N. 2004. Neuroligin 2 is exclusively localized to inhibitory synapses. Eur J Cell Biol 83: 449-456.

Varoqueaux F, Aramuni G, Rawson RL, Mohrmann R, Missler M, Gottmann K, Zhang W, Sudhof TC, Brose N. 2006. Neuroligins determine synapse maturation and function. Neuron 51: 741-754.

Vogel C, Teichmann SA, Chothia C. 2003. The immunoglobulin superfamily in Drosophila melanogaster and Caenorhabditis elegans and the evolution of complexity. Development 130: 6317-6328.

Waites CL, Craig AM, Garner CC. 2005. Mechanisms of vertebrate synaptogenesis. Annu Rev Neurosci 28: 251-274.

Walsh FS, Doherty P. 1997. Neural cell adhesion molecules of the immunoglobulin superfamily: Role in axon growth and guidance. Annu Rev Cell Dev Biol 13: 425-456.

Walsh CA, Morrow EM, Rubenstein JL. 2008. Autism and brain development. Cell 135: 396-400.

Wang X, Su H, Bradley A. 2002a. Molecular mechanisms governing Pcdh- $\gamma$ gene expression: Evidence for a multiple promoter and cis-alternative splicing model. Genes \& Dev 16: 1890-1905.

Wang X, Weiner JA, Levi S, Craig AM, Bradley A, Sanes JR. 2002b. $\gamma$ protocadherins are required for survival of spinal interneurons. Neuron 36: 843-854.

Wang CY, Chang K, Petralia RS, Wang YX, Seabold GK, Wenthold RJ. 2006. A novel family of adhesion-like molecules that interacts with the NMDA receptor. J Neurosci 26: $2174-2183$.

Washbourne P, Dityatev A, Scheiffele P, Biederer T, Weiner JA, Christopherson KS, El-Husseini A. 2004. Cell
Cell Adhesion, the Backbone of the Synapse

adhesion molecules in synapse formation. $J$ Neurosci 24: 9244-9249.

Weiner JA, Wang X, Tapia JC, Sanes JR. 2005. $\gamma$ protocadherins are required for synaptic development in the spinal cord. Proc Natl Acad Sci 102: 8-14.

Wohrn JC, Puelles L, Nakagawa S, Takeichi M, Redies C. 1998. Cadherin expression in the retina and retinofugal pathways of the chicken embryo. J Comp Neurol 396: $20-38$.

Wyszynski M, Kim E, Dunah AW, Passafaro M, Valtschanoff JG, Serra-Pages C, Streuli M, Weinberg RJ, Sheng M. 2002. Interaction between GRIP and liprin- $\alpha /$ SYD2 is required for AMPA receptor targeting. Neuron 34: 39-52.

Yamada S, Nelson WJ. 2007. Synapses: Sites of cell recognition, adhesion, and functional specification. Annu Rev Biochem 76: 267-294.

Yamagata M, Herman JP, Sanes JR. 1995. Lamina-specific expression of adhesion molecules in developing chick optic tectum. J Neurosci 15: 4556-4571.

Yamagata M, Sanes JR, Weiner JA. 2003. Synaptic adhesion molecules. Curr Opin Cell Biol 15: 621-632.

Yamamoto M, Ueda R, Takahashi K, Saigo K, Uemura T. 2006. Control of axonal sprouting and dendrite branching by the Nrg-Ank complex at the neuron-glia interface. Curr Biol 16: 1678-1683.

Zeng X, Sun M, Liu L, Chen F, Wei L, Xie W. 2007. Neurexin-1 is required for synapse formation and larvae associative learning in Drosophila. FEBS Lett 581: 2509-2516.

Zhai RG, Bellen HJ. 2004. The architecture of the active zone in the presynaptic nerve terminal. Physiology (Bethesda) 19: $262-270$.

Zhen M, Jin Y. 1999. The liprin protein SYD-2 regulates the differentiation of presynaptic termini in C. elegans. Nature 401: 371-375.

Zhong Y, Budnik V, Wu CF. 1992. Synaptic plasticity in Drosophila memory and hyperexcitable mutants: Role of cAMP cascade. J Neurosci 12: 644-651.

Zhu H, Luo L. 2004. Diverse functions of N-cadherin in dendritic and axonal terminal arborization of olfactory projection neurons. Neuron 42: 63-75. 


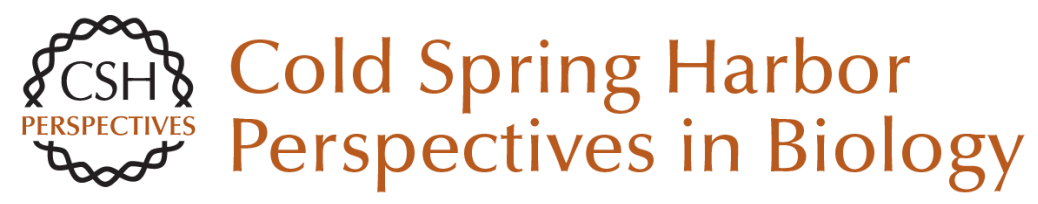

\title{
Cell Adhesion, the Backbone of the Synapse: "Vertebrate" and "Invertebrate" Perspectives
}

\author{
Nikolaos Giagtzoglou, Cindy V. Ly and Hugo J. Bellen
}

Cold Spring Harb Perspect Biol 2009; doi: 10.1101/cshperspect.a003079 originally published online September 9, 2009

\section{Subject Collection Cell-Cell Junctions}

Vascular Endothelial (VE)-Cadherin, Endothelial

Adherens Junctions, and Vascular Disease Maria Grazia Lampugnani, Elisabetta Dejana and Costanza Giampietro

Adherens Junctions and Desmosomes Coordinate Mechanics and Signaling to Orchestrate Tissue Morphogenesis and Function: An Evolutionary Perspective Matthias Rübsam, Joshua A. Broussard, Sara A. Wickström, et al.

Cell-Cell Contact and Receptor Tyrosine Kinase Signaling Christine Chiasson-MacKenzie and Andrea I. McClatchey

Hold Me, but Not Too Tight--Endothelial Cell-Cell Junctions in Angiogenesis

Anna Szymborska and Holger Gerhardt

Connexins and Disease

Mario Delmar, Dale W. Laird, Christian C. Naus, et al.

Cell Junctions in Hippo Signaling Ruchan Karaman and Georg Halder
Signaling by Small GTPases at Cell-Cell Junctions: Protein Interactions Building Control and Networks Vania Braga

Making Connections: Guidance Cues and

Receptors at Nonneural Cell-Cell Junctions Ian V. Beamish, Lindsay Hinck and Timothy E. Kennedy

The Cadherin Superfamily in Neural Circuit Assembly James $D$. Jontes

Mechanosensing and Mechanotransduction at Cell-Cell Junctions Alpha S. Yap, Kinga Duszyc and Virgile Viasnoff

Beyond Cell-Cell Adhesion: Sensational

Cadherins for Hearing and Balance Avinash Jaiganesh, Yoshie Narui, Raul Araya-Secchi, et al.

Cell-Cell Junctions Organize Structural and Signaling Networks Miguel A. Garcia, W. James Nelson and Natalie Chavez

For additional articles in this collection, see http://cshperspectives.cshlp.org/cgi/collection/

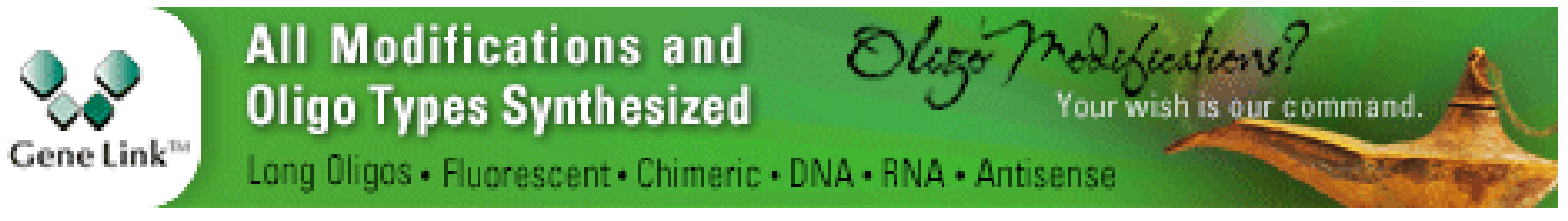


Loss of E-Cadherin-Dependent Cell-Cell Adhesion and the Development and Progression of Cancer Heather C. Bruner and Patrick W.B. Derksen

Desmosomes and Intermediate Filaments: Their Consequences for Tissue Mechanics

Mechthild Hatzfeld, René Keil and Thomas M. Magin
Cell Biology of Tight Junction Barrier Regulation and Mucosal Disease

Aaron Buckley and Jerrold R. Turner

Integration of Cadherin Adhesion and

Cytoskeleton at Adherens Junctions

René Marc Mège and Noboru Ishiyama

For additional articles in this collection, see http://cshperspectives.cshlp.org/cgi/collection/

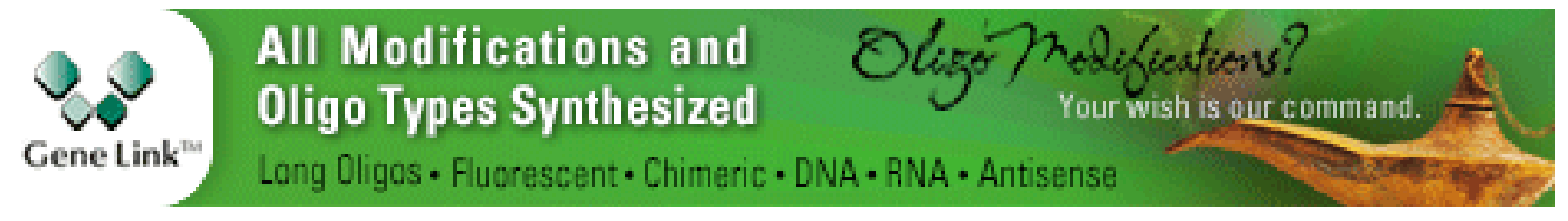

Copyright @ 2009 Cold Spring Harbor Laboratory Press; all rights reserved 